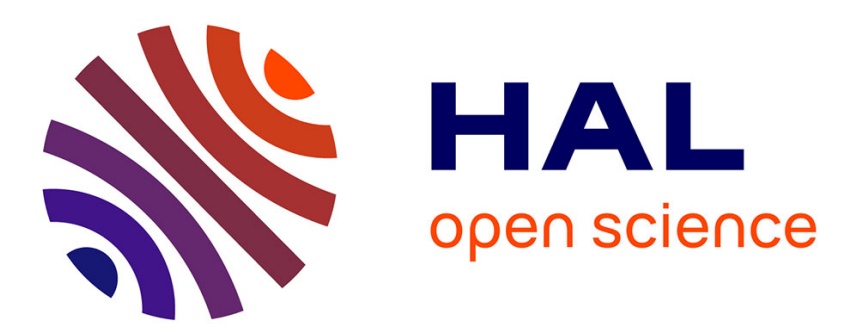

\title{
Chitosan antimicrobial and eliciting properties for pest control in agriculture: a review
}

\author{
Ke Xing, Xiao Zhu, Xue Peng, Sheng Qin
}

\section{To cite this version:}

Ke Xing, Xiao Zhu, Xue Peng, Sheng Qin. Chitosan antimicrobial and eliciting properties for pest control in agriculture: a review. Agronomy for Sustainable Development, 2015, 35 (2), pp.569-588. 10.1007/s13593-014-0252-3 . hal-01284280

\section{HAL Id: hal-01284280 \\ https://hal.science/hal-01284280}

Submitted on 7 Mar 2016

HAL is a multi-disciplinary open access archive for the deposit and dissemination of scientific research documents, whether they are published or not. The documents may come from teaching and research institutions in France or abroad, or from public or private research centers.
L'archive ouverte pluridisciplinaire HAL, est destinée au dépôt et à la diffusion de documents scientifiques de niveau recherche, publiés ou non, émanant des établissements d'enseignement et de recherche français ou étrangers, des laboratoires publics ou privés. 


\title{
Chitosan antimicrobial and eliciting properties for pest control in agriculture: a review
}

\author{
Ke Xing $\cdot$ Xiao Zhu $\cdot$ Xue Peng $\cdot$ Sheng Qin
}

Accepted: 9 September 2014 / Published online: 15 October 2014

(C) INRA and Springer-Verlag France 2014

\begin{abstract}
In agriculture, current control of pathogens relies mainly on chemical fertilizers and pesticides. However, alternative solutions are needed due to concerns for public health, environmental protection, and development of resistant pests. Chitosan is a nontoxic, biodegradable biopolymer showing antimicrobial and plant-immunity eliciting properties. Here, we review chitosan antimicrobial activities, modes of action, and the elicitation of plant defense responses. The major points are the following: (1) Chitosan exhibits various inhibitory efficiency against bacteria, fungi, and viruses; (2) the five main modes of action of chitosan are electrostatic interactions, plasma membrane damage mechanism, chitosan-DNA/RNA interactions, metal chelation capacity of chitosan, and deposition onto the microbial surface; (3) the elicitation of plant defense responses by chitosan may be related to various pathogenesis-related proteins, defense-related enzymes, and secondary metabolites accumulation, as well as the complex signal transduction network. The facing problems and strategies for antimicrobial mechanism research and agricultural application of chitosan are also discussed.
\end{abstract}

Keywords Chitosan · Plant diseases · Antimicrobial . Defense responses $\cdot$ Signal transduction $\cdot$ Agriculture

K. Xing $\cdot$ X. Zhu $\cdot$ X. Peng $(\bowtie)$

School of Life Science, Jiangsu Normal University,

Xuzhou 221116, Jiangsu, People's Republic of China

e-mail: pengxue@jsnu.edu.cn

\section{S. Qin $(\bowtie)$}

The Key Laboratory of Biotechnology for Medicinal Plant of Jiangsu

Province, Jiangsu Normal University, Xuzhou 221116, Jiangsu,

People's Republic of China

e-mail: shengqin@jsnu.edu.cn
Contents

1. Introduction

2. Antimicrobial activities of chitosan

2.1 Against fungi

2.2 Against bacteria

2.3 Against viruses

3. Antimicrobial mechanisms of chitosan

3.1 Electrostatic interactions

3.2 Membrane damage mechanism

3.3 Chitosan-DNA/RNA interactions

3.4 Metal chelation capacity of chitosan

3.5 Deposition onto the microbial surface

4. Elicitation of plant defense responses by chitosan

4.1 Pathogenesis-related proteins

4.2 Defense-related enzymes

4.3 Defense-related secondary metabolites accumulation

4.3.1 Phytoalexins

4.3.2 Lignin

4.3.3 Suberization

4.3.4 Phenolic compounds

4.3.5 Callose

4.4 Signal Transduction

4.4.1 Extracellular signal perception of chitosan

4.4.2 Intracellular signal perception of chitosan

4.4.3 Signal transduction of chitosan with other signal molecules

5. Conclusion and future perspectives

\section{Introduction}

In agriculture, pathogens cause many important plant diseases and are responsible for losses in crop yield and quality in all parts of the world. Besides that, many pathogenic fungi can also produce kinds of harmful toxins and metabolites in the infection process, which is a great threat to the safety of 
agricultural products. The end result of pathogens infection is a reduction in plant growth, lower yield, inferior product quality, and huge economic loss. Therefore, plant diseases need to be controlled to maintain the quality and safety of agricultural products. During the past 100 years, crop protection has relied heavily on chemical fertilizers and pesticides. However, the chemical pesticide is a double-blade sword. Excessive use of pesticides and fertilizers helps farmers raise productivity significantly, but it also harms biological diversity, natural and agricultural systems, and public health and leads to the development of resistant strains (Sun et al. 2012). As relatively recent, terms, genetic engineering, and genetic modification are ad hoc approaches that could improve plant traits, such as disease resistance and production of useful goods. However, in the face of public concerns about the safety of the genetically modified crops, alternative methods should be provided to solve the real problems in agricultural production. Therefore, it is important to develop environmentally friendly pesticides and techniques that can be used to reduce pesticide use while ensuring the healthy development of plants and sustainable agriculture. Natural products are an excellent alternative to synthetic pesticides as a means to reduce negative impacts to human health and the environment.

Chitosan, $\beta$-(1,4)-2-amino-2-deoxy-D-glucose, is a natural versatile biopolymer derived by partially deacetylation of chitin (Fig. 1), mainly as the structural component of the exoskeletons of crustaceans and insects, as well as in some fungal cell walls (Sanford 2003). In 1859, French C. Rouget reported finding chitosan after boiling chitin in potassium hydroxide. From then on, chitosan has attracted considerable interest in various fields due to its unique biological activities, such as biocompatibility (Hsu et al. 2011; Mi et al. 2002), biodegradability (Kim et al. 2011), nontoxicity (Shi et al. 2006), antimicrobial activity ( $\mathrm{Li}$ et al. 2008; Rabea et al.
2009), antitumor activity (Toshkova et al. 2010), and immune-enhancing effect ( $\mathrm{Li}$ et al. 2013c; Zaharoff et al. 2007). These properties make chitosan a promising candidate for medicine (Tan et al. 2013), food (Dutta et al. 2009; Qiu et al. 2014), cosmetic (Ray 2011), water treatment (Bhatnagar and Sillanpää 2009), and biomedical engineering industries (Silva et al. 2012; Upadhyaya et al. 2013), as well as for many agricultural uses (Cota-Arriola et al. 2013; El-Hadrami et al. 2010). In fact, a number of commercial applications of chitosan benefit from its antimicrobial activity. As a versatile material, chitosan exhibits proved antimicrobial activities against fungi, bacteria, and viruses and acts as an elicitor of plant defense mechanisms. With the wide-spectrum antimicrobial activities, chitosan has been utilized to reduce or prevent the spread of pathogens ( $\mathrm{Li}$ et al. 2013a; Mansilla et al. 2013; Fig. 2) or to enhance plant innate immunity defenses (El-Ghaouth et al. 1994; Amborabé et al. 2008; Fondevilla and Rubiales 2012). The interplay of antimicrobial and eliciting properties makes chitosan a potential antimicrobial agent to control plant disease caused by pathogens. Furthermore, chitosan is an abundant and biodegradable biopolymer derived from chitin, which is the second large renewable resource after cellulose in the world. In addition, toxicity tests that reported the lethal dose for $50 \%$ of test animals $\left(\mathrm{LD}_{50}\right)$ of chitosan in laboratory mice exceed $16 \mathrm{~g} /$ day/Kg body weight, which is very close to that of salt or sugar (Dodane and Vilivalam 1998; Singla and Chawla 2001). Therefore, the development of chitosan pesticide has potential social and economic benefits.

Based on the current state of research and progress in corresponding areas, this review is organized into sections discussing the antimicrobial properties of chitosan against plant pathogens (including fungi, bacteria, and viruses), the modes of action as antimicrobial compounds, and the ability to elicit natural plant defense responses.
Fig. 1 The structure of chitin and chitosan. Chitin and chitosan are nitrogenous polysaccharides. The structure of the chitin molecule is similar to that of cellulose, but it is composed of the units of 2acetylamino-2-deoxy-Dglucopyranose bound by a glycosidic bond. In contrast to chitin, chitosan amino groups are not mostly acetylated
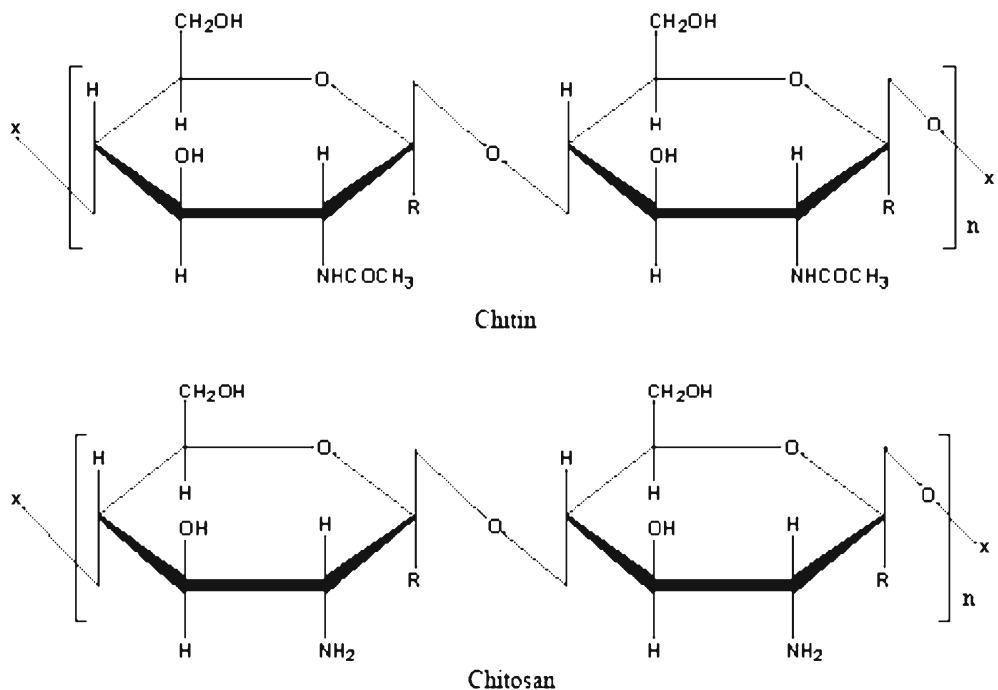


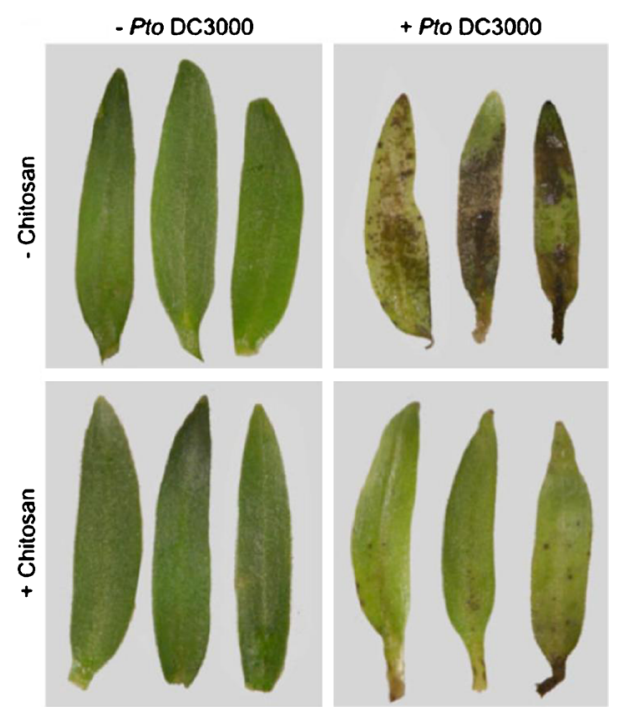

Fig. 2 Chitosan counteracted Pto DC3000 bacterial colonization in tomato seedlings. Disease phenotype of seedlings pretreated with $10 \mu \mathrm{g} / \mathrm{mL}$ chitosan (+Chitosan) or $0.001 \%(v / v)$ acetic acid (-Chitosan) and then immersed in Pto DC3000 cell suspension (+Pto DC3000) or sterile distilled water containing $0.025 \%(v / v)$ SILWET L-77 plus $10 \mathrm{mM}$ $\mathrm{MgCl}_{2}$ (-Pto DC3000). Photographs were taken at 7 days postinoculation. Tomato seedlings were healthy (-Chitosan and -Pto DC3000); it could induce the characteristic symptom of bacterial speck of tomato and make the seedling wilting and tawny (-Chitosan and + Pto DC3000); tomato seedlings remain healthy which showed that chitosan was harmless to plants (+Chitosan and -Pto DC3000); it significantly decreased bacterial damages in cotyledons which revealed that chitosan contributed to counteract bacterial growth in tomato seedlings ( + Chitosan and + Pto DC3000)

\section{Antimicrobial activities of chitosan}

In 1979, the first study reported that chitosan showed a broad range of activities and a high inactivation rate against both Gram-positive and Gram-negative bacteria (Allan and Hadwiger 1979). Since then, many studies on the antimicrobial properties of chitosan and its derivatives have been reported (No et al. 2002; Xing et al. 2008; Lee and Je 2013). In modern agriculture, lots of plant pathogens have been found to be sensitive to chitosan (Manjunatha et al. 2008; Rabea et al. 2009; Li et al. 2013a, b, c). Although chitosan has been proved to be effective against bacteria, fungi, and viruses, it exhibits different inhibitory efficiencies against different microbial species.

\subsection{Against fungi}

As a broad-spectrum fungicide, chitosan has been shown to be fungicidal against several fungal plant pathogens (Liu et al. 2001; Wiśniewska-Wrona et al. 2007; Rabea and Steurbaut 2010; Table 1). Chitosan can effectively inhibit the development of phytopathogenic fungi at different life-cycle stages. For instance, chitosan completely inhibited spore germination, germ tube elongation, and mycelial growth of Alternaria kikuchiana Tanaka and Physalospora piricola Nose at $5.0 \mathrm{~g} /$ $\mathrm{L}$ in vitro (Meng et al. 2010). In pear fruit, treatments with chitosan reduced the disease incidence and inhibited the lesion expansion caused by these two fungal pathogens (Meng et al. 2010). In commercial winegrapes, chitosan effectively inhibited growth of Botrytis cinerea in liquid culture and suppressed gray mold on detached grapevine leaves and bunch rot (Reglinski et al. 2010). Chitosan exhibited strong antifungal activity against Rhizoctonia solani, the rice sheath blight pathogen. Two types of acid-soluble chitosan (with different degrees of deacetylation) caused a 60-91\% inhibition in mycelial growth, 31-84 \% inhibition of disease incidence, and 66-91\% inhibition in lesion length (Liu et al. 2012).

Chemical modifications as an approach are efficient in enhancing the biological activity against some economic plant pathogenic fungi and bacteria and widening their applications (Guo et al. 2006). Chitosan hydrochlorides, even at the lowest test concentration of $0.0025 \%$, inhibited growth of the Candida species significantly (Seyfarth et al. 2008). In the bioassay of Fusarium oxysporum and Pythium debaryanum, $N$-(benzyl) chitosan derivatives exhibited high inhibition percentage of spore germination at $1,000 \mathrm{mg} / \mathrm{L}$ (Rabea et al. 2009).

As evaluated by leakage of proteinaceous and other UVabsorbing material, there was no significant increase in leakage and any apparent symptoms of phytotoxicity when plants were grown in the presence of chitosan, even at a higher chitosan concentration (Kong et al. 2010), which showed that chitosan was harmless to plants.

\subsection{Against bacteria}

Chitosan and its derivatives inhibited the growth of a wide variety of bacterial plant pathogens (Liu et al. 2001; Wiśniewska-Wrona et al. 2007; Rabea and Steurbaut 2010; Badawy et al. 2014; Table 1). Based on the available evidences, bacteria appear to be generally less sensitive to the antimicrobial action of chitosan than fungi (Kong et al. 2010). In various microbial species, the antibacterial efficiency of chitosan against Gram-positive and Gram-negative bacteria is different, however, somewhat controversial. Several researchers have demonstrated that chitosan exhibited higher inhibition effects on Gram-positive bacteria than on Gramnegative bacteria (No et al. 2002; Tayel et al. 2010; Lee and Je 2013). Concerning the bacteria surface structure, Grampositive bacteria tend to have a loose cell wall, while Gramnegative bacteria have an outer membrane structure in the cell wall. As a polymeric macromolecule, chitosan is unable to pass through the outer membrane of Gram-negative bacteria, since this membrane functions as an efficient outer permeability barrier against macromolecules (Helander et al. 2001). While in other studies, Gram-negative bacteria were more 
Table 1 The minimum growth inhibitory concentrations (MIC) of native chitosan or its derivatives against fungal and bacterial plant pathogens

\begin{tabular}{lll}
\hline Microorganisms & Chitosan samples & MIC (ppm) \\
\hline Fungi & & \\
Botrytis cinerea & Chitosan & 10 \\
Drechstera sorokiana & Chitosan & 10 \\
Fusarium oxysporum & Chitosan & 100 \\
Micronectriella nivalis & Chitosan & 10 \\
Piricularia oryzae & Chitosan & 5,000 \\
Rhizoctonia solani & Chitosan & 1,000 \\
Trichophyton equinum & Chitosan & 2,500 \\
Bacteria & & \\
Agrobacterium tumefaciens & $N$-(o,o-dichlorobenzyl) chitosan & 500 \\
Agrobacterium tumefaciens & Quaternary $N$-(benzyl) chitosan & 500 \\
Agrobacterium tumefaciens & $N$-(benzyl) chitosan & 800 \\
Clavibacter michganensis subsp. michganensis & Chitosan & 1,000 \\
Erwinia carotovora & Chitosan & 200 \\
Erwinia carotovora & $N$-(o,o-dichlorobenzyl) chitosan & 480 \\
Erwinia carotovora & Quaternary $N$-(benzyl) chitosan & 600 \\
Erwinia carotovora & $N$-(benzyl) chitosan & 700 \\
Erwinia carotovora & $N$-( $\alpha$-methylcinnamyl) chitosan & 1,025 \\
Erwinia carotovora subsp. carotovora & Chitosan & 5,000 \\
Xanthomonas campestris & Chitosan & 500 \\
\hline & & \\
\hline & &
\end{tabular}

susceptible to chitosan (Park et al. 2004; Du et al. 2009). They suggested that hydrophilicity in Gram-negative bacteria is significantly higher than that in Gram-positive bacteria, making them more sensitive to chitosan (Chung et al. 2004). Moreover, the Gram-negative cell envelope contains an additional outer membrane composed by phospholipids and lipopolysaccharides, which face the external environment. The highly charged nature of lipopolysaccharides confers an overall negative charge to the Gram-negative cell wall. Therefore, Gram-negative bacteria with high electronegative charge will interact more effectively with the polycationic chitosan compared with Gram-positive bacteria. Besides microorganism species, diverse consequences may be due to various initial reaction material and conditions, such as $\mathrm{pH}$, molecular weight, and degree of deacetylation of chitosan, etc. (Kong et al. 2010; Younes et al. 2014).

The in vitro antibacterial effect of chitosan and its ability in protection of watermelon seedlings from Acidovorax citrulli were evaluated. The disease index of watermelon seedlings planted in soil and the death rate of seedlings planted in perlite were significantly reduced by chitosan at $0.40 \mathrm{mg} / \mathrm{mL}$ compared with the pathogen control (Li et al. 2013b). Chitosan solution at $0.10 \mathrm{mg} / \mathrm{mL}$ markedly inhibited the growth of Xanthomonas pathogenic bacteria from different geographical origins. The surviving cell numbers in the chitosan solution decreased more than $3.86 \log _{10} \mathrm{CFU} / \mathrm{mL}$ compared with the control after $6 \mathrm{~h}$ of incubation regardless of the bacterial strain (Li et al. 2008). As shown in Fig. 2, pretreatment of tomato seedlings with $10 \mu \mathrm{g} / \mathrm{mL}$ chitosan before Pseudomonas syringae pv. tomato DC3000 (Pto DC3000) inoculation significantly decreased bacterial damages in cotyledons compared with control (Mansilla et al. 2013). Not only does chitosan inhibit planktonic cell growth but also it affects the already established biofilms. Unexpectedly, log reductions were in some cases higher for biofilm than for planktonic cells, deserving further more detailed work (Orgaz et al. 2011).

\subsection{Against viruses}

Compared with the studies of antibacterial and antifungal activity of chitosan, relatively few research studies of its antiviral activity have been reported ( $\mathrm{Su}$ et al. 2009). The antiviral activity of chitosan in animals, microorganisms, and plants has been reviewed (Chirkov 2002; Wang et al. 2012). Chitosan inhibited viral infections in animal cells and prevented the multiplication of bacteriophages in infected cultures of microorganisms (Chirkov et al. 2001; Chirkov 2002). In plants, chitosan induced resistance toward viral diseases and inhibited the systemic spreading of viruses and viroids so that most or all plants treated with chitosan did not develop systemic viral infection (Chirkov 2002; Rabea et al. 2003). Low-molecular chitosan inhibited the formation of local necroses induced by tobacco mosaic virus for $50-90 \%$ (Davydova et al. 2011). Actually, the direct inhibitory effect of chitosan on viruses was mainly manifested in the inactivation 
of viruses. Chitosan was effective in inhibiting coliphage infection and the replication of 1-97 A phage in Bacillus thuringiensis culture. When added to a phage suspension, chitosan decreased its titer. Electron microscopic observations showed that chitosan caused structural changes in phage particles and damaged their integrity (Chirkov 2002). Electron microscope photographs of tobacco mosaic virus suspension showed that the number of virus particles was notably decreased and most of them twisted together and bound into a bundle (Hu et al. 2009).

\section{Antimicrobial mechanism of chitosan}

Ever since the wide-spectrum antimicrobial activity of chitosan was discovered, great interests in this polymer and its derivatives have increased in recent years due to their unique properties. Undoubtedly, more and more research studies proved their potential use in agriculture, medical industry, food industry, and so on. As we all know, research of antimicrobial mechanisms is an absolutely necessary stage of the microbicide development. However, the exact mechanisms of the antimicrobial activities of chitosan and its derivatives are still unknown, which limit their further application to some extent. In the past decades, various mechanisms of action have been proposed to explain the antimicrobial activity of chitosan (Table 2). On the basis of present research studies, the antimicrobial mechanisms of chitosan and its derivatives can be summarized as follows.

\subsection{Electrostatic interactions}

Polycationic polymer chitosan has so many reactive amino groups in its structure that can be protonated, and thus the polymer will bear positive charge, while chitin as an $N$ acetylglucosamine polymer does not show any antimicrobial activity. Differences in the structures might account for their varying inhibition effects, which also suggest that the presence of amino groups is the base of the antimicrobial activity of chitosan. Because of the stable crystalline structure, chitosan is normally insoluble in water, but soluble in dilute aqueous acidic solutions below its $\mathrm{pKa}(\sim 6.3)$, in which amine $\left(-\mathrm{NH}_{2}\right)$ groups in glucosamine units are converted into the soluble protonated form $\left(-\mathrm{NH}_{3}{ }^{+}\right.$) (Madihally and Matthew 1999; Pillai et al. 2009; Silva et al. 2012). It was observed that dimethylaminoethyl-chitosan 90 prepared from $90 \%$ deacetylated chitosan had more activity than dimethylaminoethyl-chitosan 50 prepared from $50 \%$ deacetylated chitosan (Je and Kim 2006), which meant that the amino group $\left(\mathrm{NH}_{3}{ }^{+}\right)$as the active functional group was found to be essential to the antibacterial activity of chitosan (Chung and Chen 2008). However, a selection of three chitosan derivatives with increasing positive charge render the prevailing electrostatic explanations questionable, since chitosan-thioglycolic acid (slightly positive zeta potential) had superior effects compared with trimethyl chitosan (highly positive zeta potential) with all microbes tested (Geisberger et al. 2013). However, these observations did not repudiate electrostatic interactions of chitosan-pathogens totally and revealed that the antimicrobial action of water-soluble chitosans was dependent on the degree of deacetylation and the substituted group (Je and Kim 2006). It shed light on the modes of action of chitosan that is probably more complex, involving a series of molecules that may ultimately lead to a killing process.

The Gram-positive bacterial cell wall is made up of thick peptidoglycan layer that is rich in teichoic acids, which are negatively charged because of the presence of phosphate groups in the structure. While in Gram-negative bacteria, lipopolysaccharides impart a strongly negative charge to the bacterial surface. Also, there are similar negatively charged compounds (e.g., proteins and glycoproteins) in the fungal cell membrane and viral envelope. Thus, the positively charged chitosan molecules potentially interact with negatively charged pathogen surfaces, which is termed as electrostatic interactions, can destroy the cell structure, cause extensive cell surface alterations, and increase membrane permeability (Rabea et al. 2003; Chung et al. 2004; Liu et al. 2004), leading to the leakage of intracellular substances and ultimately resulting in impairment of pathogen vital activities (Helander et al. 2001; Zakrzewska et al. 2005; Je and Kim 2006).

To verify the possible involvement of teichoic acids of Staphylococcus aureus in chitosan's antimicrobial activity and to analyze their role in chitosan susceptibility, Raafat et al. (2008) tested $S$. aureus strain SA113 together with four mutants lacking one or more genes involved in teichoic acids biosynthesis. The minimum growth inhibitory concentration (MIC) of chitosan for wild-type $S$. aureus SA113 was $84.8 \mu \mathrm{g} /$ $\mathrm{mL}$. The $S$. aureus SA113 $\Delta$ tagO deletion mutant, a completely lacked wall teichoic acids, was the most resistant of the strains to chitosan, with an MIC at $545.5 \mu \mathrm{g} / \mathrm{mL}$ (more than 5fold higher than the wild type). The $S$. aureus SA113 $\Delta$ dltA mutant, which lacked the D-alanine modification in teichoic acids, as a result of which the cells carried an increased negative surface charge, was almost 100 times more susceptible to the action of chitosan, with an MIC as low as $0.9 \mu \mathrm{g}$ / $\mathrm{mL}$. These data clearly indicated that teichoic acids played a major role in the chitosan-bacteria interaction since the lack of teichoic acids in Staphylococcus resulted in a less negatively charged cell wall and increased resistance to chitosan, and further substantiated the hypothesis that the polycationic nature of chitosan is a major factor contributing to its antimicrobial activity.

To clarify the possible role of phospholipids, the main composition of teichoic acids, involved in the antimicrobial 


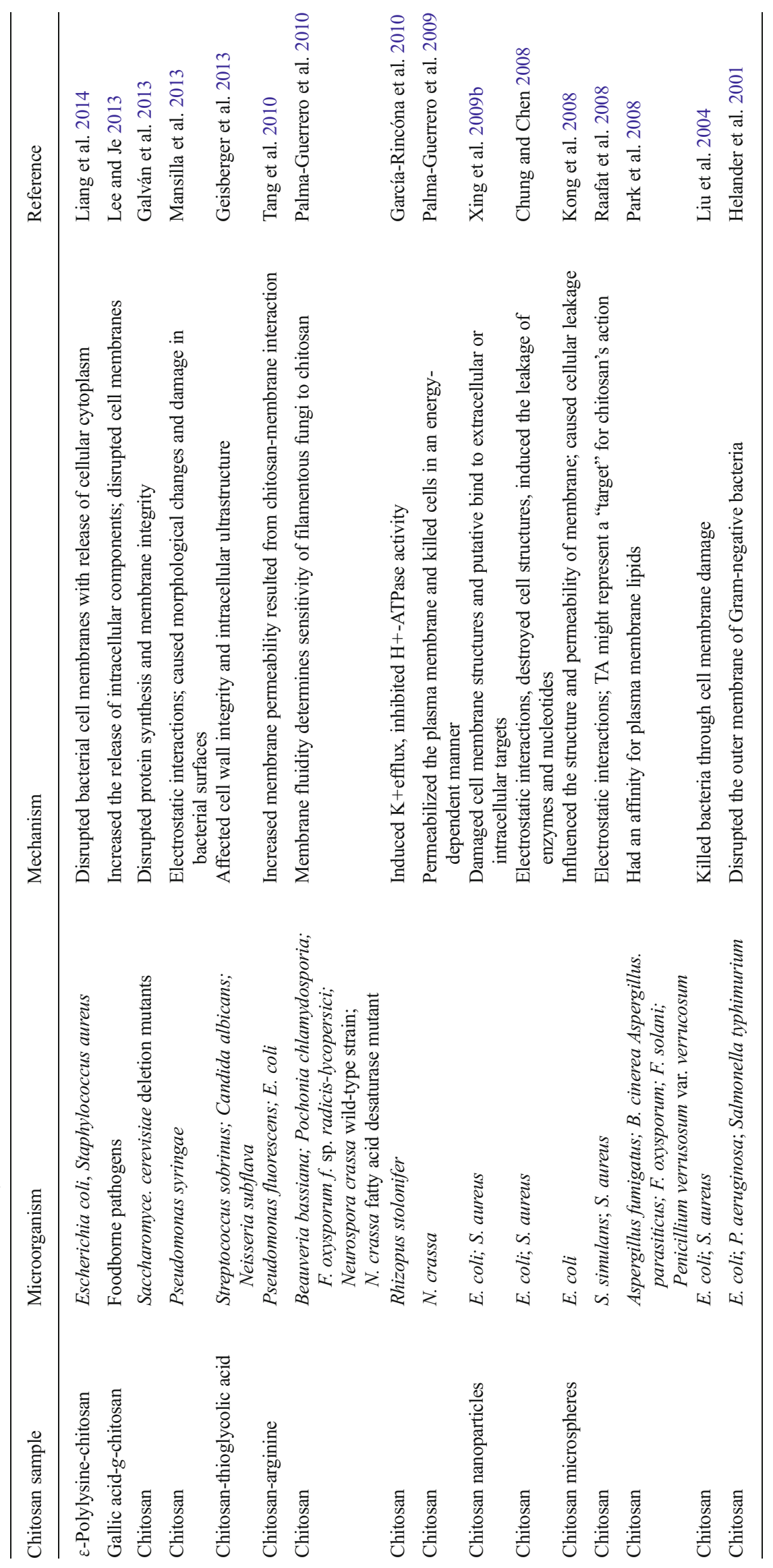


action of chitosan, lecithin and $\mathrm{Na}_{3} \mathrm{PO}_{4}$ were used to simulate the effect of phospholipids and phosphate groups in the cytoplasmic membrane. Results showed that no matter whether treated with lecithin or phosphate groups, chitosan could inhibit the growth of Escherichia coli effectively. It meant that lecithin or phosphate groups did not influence the interaction between chitosan and E. coli. While in the case of $S$. aureus, the addition of lecithin or phosphate groups apparently influenced the inhibition rate (Xing et al. 2009b). Therefore, it is presumable that phospholipids might be a target molecule in the chitosan-pathogen interaction that occurred at the cell surface of $S$. aureus. The different effects of lecithin and phosphate groups on the antibacterial activity against E. coli and S. aureus have proved once again that the mechanisms of the antimicrobial activity of chitosan were different for Gram-positive and Gram-negative bacteria.

\subsection{Membrane damage mechanism}

A major function of the cell wall and cell membrane is to protect the interior substances so that they would not leak to the cell exterior. The electrostatic interaction, between the positively charged amino groups of chitosan and the negatively charged residues of macromolecules exposed at the microbial surfaces, changed the permeability of cell membranes and thereby caused the death of bacteria (Helander et al. 2001). Chitosan was found to react with both the cell wall and cell membrane, but not simultaneously, indicating that the inactivation of pathogens by chitosan occurs via a two-step sequential mechanism, i.e., an initial separation of the cell wall from its cell membrane, followed by destruction of the cell membrane (Chung and Chen 2008).

Light and electron microscope investigations revealed that growth inhibition of $F$. oxysporum as a response to chitosan was accompanied by marked cellular changes, which included hyphal swelling, increased vacuolation, retraction, and alteration of the plasma membrane, cytoplasm aggregation, and abnormal cell wall deposition (Benhamou 1992). In electron micrographs, the outer membrane of chitosan-treated E. coli was disrupted and covered by an additional tooth-like layer. In micrographs of chitosan-treated $S$. aureus, the membrane of dividing cells was disrupted in the constricting region with the loss of cell contents (Liu et al. 2004). Similar results were reported by lots of research studies with different chitosan derivatives and tested strains (Lee and Je 2013).

However, whether such remarkable modification is resulted from the direct effect of chitosan is unknown. This is because chitosan solution cannot be directly observed in electron micrographs, which makes it difficult to investigate the mode of action of chitosan on microbes. Our previous work gave a direct evidence for such interaction, which employed oleoyl-chitosan nanoparticles, combined with E. coli and $S$. aureus to explore the antibacterial interaction. Electron microscopy clearly demonstrated oleoyl-chitosan nanoparticles with intact spherical structure adhered to the surface of $E$. coli and $S$. aureus and efficiently permeabilized bacterial cell membranes (Xing et al. 2009a; Fig. 3). The morphological changes were observed more obviously as the contact time increased continuously (Xing et al. 2009a).

Besides morphological changes, detection and quantification of amino acids residues in membrane proteins reflected the

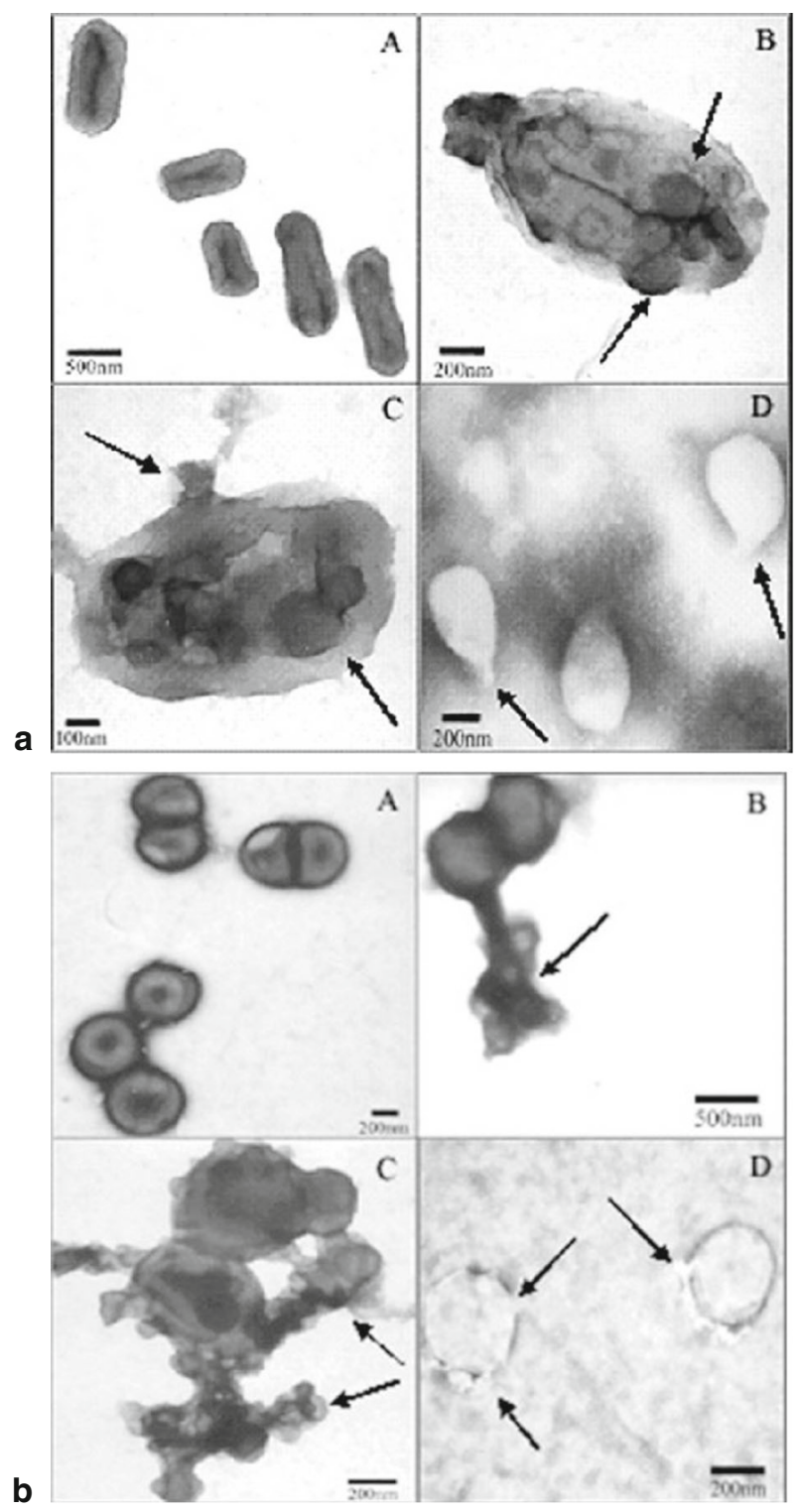

Fig. 3 Transmission electron microscope of E. coli (a) and S. aureus (b) cells treated with $300 \mathrm{mg} / \mathrm{L}$ oleoyl-chitosan nanoparticles for up to 30 min. a Untreated cell displayed a smooth and compact surface. b Some nanoparticles with intact spherical structure (arrows pointed to) adhering to the surface of cell after nanoparticles treated for $5 \mathrm{~min}$. $\mathbf{c}$ Deep roughening and collapse of the cell surface was found after $15 \mathrm{~min}$. d Apparent holes and loss of cell contents (arrows pointed to) were observed in lysed bacteria, surrounded by dark floccules instead of spherical nanoparticles after $30 \mathrm{~min}$ 
integrity of cell membranes indirectly. When antibacterial agents interacted with cell membranes, the conformation of membrane proteins would be changed, and then Tyr residues located inside the membrane would be exposed to the surface (Ye et al. 2007). After treatment with oleoyl-chitosan nanoparticles, the fluorescence intensity of Tyr residues increased in E. coli and $S$. aureus, which indicated that chitosan influenced the structure of cell membranes by interacting with proteins on the cell membrane of the bacteria (Xing et al. 2009b). Accordingly, it is speculated that membrane proteins would be one of the target molecules on cell surfaces for chitosan's action.

The efflux of potassium ions was identified as an early response of the cell to the presence of some cationic compounds. A rapid efflux of potassium depended on the chitosan concentration was observed. In addition, there was an important inhibitory effect of chitosan on $\mathrm{H}^{+}$-ATPase activity in the plasma membrane of Rhizopus stolonifer. The decrease in the $\mathrm{H}^{+}$-ATPase's activity could provoke the accumulation of protons inside the cell, which would result in the inhibition of the chemiosotic driven transport that allows the $\mathrm{H}^{+} / \mathrm{K}^{+}$exchange (García-Rincóna et al. 2010).

As we mentioned above, the plasma membrane protected the cell from harmful substances present in the external environment from entering into the interior. Why does the plasma membrane form a barrier to chitosan in some species but not in others? By imaging fluorescently labeled chitosan, a recent work shed new light on this question. It was observed that chitosan bound to the conidial surfaces of all species tested but only consistently permeabilizes the plasma membranes of chitosan-sensitive fungi. This suggested that the plasma membrane formed a barrier to chitosan in chitosan-resistant fungi but not in chitosan-sensitive fungi. Fatty acid analysis revealed that the plasma membranes of chitosan-sensitive fungi were shown to have more polyunsaturated fatty acids than chitosan-resistant fungi, suggesting that their permeabilization by chitosan may be dependent on membrane fluidity. Moreover, a fatty acid desaturase mutant of Neurospora crassa with reduced plasma membrane fluidity exhibited increased resistance to chitosan. These findings suggested a new strategy for antifungal therapy by increasing plasma membrane fluidity to make fungi more sensitive to fungicides such as chitosan (Palma-Guerrero et al. 2010).

Fluorescently labeled chitosan was found to be taken up and accumulated in bacteria and fungi by many researchers. Little is known, however, about its mode of endocytical internalization by fungal cells. A study focused on the internalization of chitosan by living cells made a number of novel findings (Palma-Guerrero et al. 2009). Sodium azide and low temperature $\left(4^{\circ} \mathrm{C}\right)$, two standard treatments to inhibit ATP production (Atkinson et al. 2002), prevented the endocytic marker FM4-64 uptake by chitosan-treated conidia indicating that chitosan-induced permeabilization of the plasma membrane was ATP-dependent but did not involve endocytosis.

\subsection{Chitosan-DNA/RNA interactions}

Chitosan with lower molecular weight is assumed to be able to pass through the bacterial cell wall (Sudarshan et al. 1992; Goy et al. 2009), destroy intracellular components from colloidal state to flocculation and degeneration, disrupt the normal physiological metabolic activity of bacteria, or directly interfere with genetic materials (Come et al. 2003; Issam et al. 2005), and then inhibit the reproduction of bacteria, resulting in the death of microorganisms ultimately. It is presumable that chitosan could bind with DNA and inhibit synthesis of messenger RNA (mRNA) through penetration toward the nuclei of the microorganisms and interfere with the synthesis of mRNA and proteins (Sudarshan et al. 1992; Rabea et al. 2003). Fluorescence micrographs evidenced that the fluorescein isothiocyanate labeled chitosan oligomers were observed at the inside of the cell. Permeated chitosan oligomers (molecular weight $=8,000$ and 5,000 ) were suggested to block the transcription from DNA to inhibit the growth of bacteria (Liu et al. 2001) and then disrupt the related protein synthesis.

Our previous studies indicated that chitosan nanoparticles efficiently permeabilized bacterial cell membranes and adhered to the bacterial surface (Xing et al. 2009a) and then penetrate into the bacteria with the contact time increased (Xing et al. 2009b). As we discussed above, the phosphate group might be an extracellular target contributing to its interaction with the positively charged chitosan, ultimately resulting in impairment of vital bacterial activity. There are also phosphate groups in the main chain of nucleic acid (DNA/RNA). It is possible that the amino groups of chitosan that possess positive charges would attract the negatively charged phosphate groups of DNA/RNA. In vitro chitosanDNA/RNA interaction obviously inhibited electrophoretic mobility of bacterial genomic DNA or total RNA on agarose gel. The brightness of bands weakened gradually as the concentration of chitosan nanoparticles increased, showing the aggravation of chitosan-DNA/RNA interactions. The possible reason might be that negative charges of DNA/RNA had been counteracted by chitosan so that they could not move in electric field accordingly. The gel-retardation experiment pointed out that DNA and RNA might be the intracellular targets of chitosan (Xing et al. 2009b).

In a recent work, about 4,600 nonessential gene deletion mutants of $S$. cerevisiae were employed to investigate the antifungal mechanism of low molecular weight chitosan. It was found that $31 \%$ of the 107 mutants most sensitive to chitosan had deletions of genes related primarily to functions involving protein synthesis. As the chitosan concentration ranged from 0.35 to $1.25 \mathrm{mg} / \mathrm{mL}$, the $\beta$-galactosidase activity was reduced from 32 to $13 \%$ of no-chitosan controls, which could be the result from interference with transcription efficiency and other processes in addition to translation (Galván et al. 2013). 


\subsection{Metal chelation capacity of chitosan}

In the cell wall of Gram-positive bacteria, peptidoglycan accounts for about $50-80 \%$ of the cellular dry weight, as well as a large number of special ingredients like teichoic acids. Phosphate groups of teichoic acids are able to attract divalent metal cations (Lambert 2002), especially $\mathrm{Mg}^{2+}$ and $\mathrm{Ca}^{2+}$, to maintain enzymatic functions and the stability of cytoplasmic membranes (Elsenhans et al. 1983). For Gram-negative bacteria, lipopolysaccharides not only increase the negative charge of the cell membrane but also have a strong affinity for cations such as $\mathrm{Mg}^{2+}$ and $\mathrm{Ca}^{2+}$. The combination of metal ions and chelating agents, such as ethylenediaminetetraacetic acid (EDTA), released lipopolysaccharides and led to the collapse of the outer membrane (Vaara 1992). As a kind of complexing reagent, chitosan is able to chelate some essential nutrients, metal ions, and trace elements necessary for the growth of bacteria and fungi. When the $\mathrm{pH}$ is below 6.0, protonated $\mathrm{NH}^{+}$groups of chitosan compete with divalent metal ions for phosphate groups in teichoic acids or lipopolysaccharide molecules. In the presence of chitosan, the cell wet weight of $P$. syringae pv. tomato DC3000 decreased $50 \%$ compared with control. However, the addition of $\mathrm{MgCl}_{2}$ rescued the values of the chitosan-treated group (Mansilla et al. 2013). The addition of $\mathrm{Mg}^{2+}$ or $\mathrm{Ca}^{2+}$ increased the concentration of positive charges in the system and weakened the bacteriostatic action that mainly depends on electrostatic forces. Therefore, the antibacterial activity of chitosan decreased obviously in a dose-dependent manner when $\mathrm{Mg}^{2+}$ and $\mathrm{Ca}^{2+}$ were added to the culture medium. It suggested that disruption of the barrier properties of the outer membrane is the first step for chitosan to exhibit antimicrobial effects.

\subsection{Deposition onto the microbial surface}

High molecular weight chitosan can deposit onto the bacterial surface and form a dense polymer film. Chitosan-treated cells exhibited altered outer membranes, the surface of which was covered by numerous vesicular structures and an additional layer of material, causing the cell envelope to appear considerably thickened (Helander et al. 2001). The thickened cell envelope prevents nutrients from entering the cell, as well as the extracellular transport of metabolite excretion. Similar to chitosan, chito-oligomers caused blockage of nutrient flow and were responsible for the growth inhibition and lysis of $E$. coli, which were evidenced by scanning electron microscopy (Vishu et al. 2005). The deposition of cationic oligomers on to the cell surface is more prominent than membrane disruption as in the case of Gram-positive bacteria, owing to stronger association of $O$-chains to the outer membrane structure (Vishu et al. 2005). Therefore, another possibility for the antimicrobial activity of chitosan is based on the formation of polymer film to damage the physiological metabolism process of the bacteria.

\section{Elicitation of plant defense responses by chitosan}

Nowadays, chitosan is considered to be a promising antimicrobial agent owing to its antibacterial, antifungal, and antiviral activities. This has led to the exploitation of its properties in various aspects of agriculture. Since the 1980s, the study of chitosan has been changed from a general sewage treatment agent to plant growth regulator, fruits and vegetables antistaling agent, soil conditioner, and seed coating agent, especially in the disease control in agricultural production. Lots of studies showed that chitosan is not only an antimicrobial agent but also an effective elicitor of plant systemic acquired resistance to pathogens (Table 3). Even applied on plants together with the biological control agents, chitosan enhanced the efficacy in the control of pathogens (Vallance et al. 2011; Abro et al. 2013). It is possible for chitosan as a new type of green pesticides to play an important role in agriculture owing to its nontoxic, biodegradable, and nonpollution characteristics.

\subsection{Pathogenesis-related proteins}

In many plant species, response to infection by plant pathogens or various abiotic stresses is accompanied by the synthesis of low molecular weight compounds, proteins, and peptides with antimicrobial activities, which are termed as pathogenesis-related proteins (Bol et al. 1990; Selitrennikoff 2001). These pathogenesis-related proteins were first detected by Van Loon and Van Kammen (1970), when they observed accumulation of various novel proteins in leaves of tobacco after tobacco mosaic virus infection. Since then, chitosan has been described as an elicitor to induce plants produce a wide range of pathogenesis-related proteins with antimicrobial activity to protect themselves from pathogen infection. Some of these pathogenesis-related proteins are hydrolytic enzymes that target cell walls, such as chitinase and $\beta$-1,3-glucanase, the markers of plant defense responses. Since there are specific hydrolytic enzymes but no corresponding substrate in plants, these enzymes may have been retained throughout evolution for the purpose of confronting challenges by insects and fungi (Hadwiger 2013).

Since insect exoskeletons and fungal cell walls contain chitin and/or $\beta$-D-glucans as major structural components, chitinase and $\beta$-1,3-glucanase are capable of catalyzing the hydrolysis of chitin and $\beta$-D-glucans, decomposing cell walls of fungi, thus preventing the growth of fungi on the plant (ElGhaouth et al. 1992; Abbasi et al. 2009). Furthermore, chitinase and $\beta$-1,3-glucanase very often act synergistically 
Table 3 Listing of some variable applications of chitosan as an elicitor of plant defense responses

\begin{tabular}{|c|c|c|c|}
\hline Plant/crop & Disease/condition & Efficacy & Reference \\
\hline Jute & Stem rot & Enhanced the activity of defense-related enzymes & Chatterjee et al. 2014 \\
\hline Rice & Leaf streak, leaf blight & Accumulated defense-related enzymes & Li et al. $2013 \mathrm{a}$ \\
\hline Watermelon & Fruit blotch disease & Direct killing effect & Li et al. $2013 b$ \\
\hline Peach & Brown rot & Enhanced antioxidant and defense-related enzymes & Ma et al. 2013 \\
\hline Pine & Pitch canker & Upregulated the expression level of defense-related enzymes & Fitza et al. 2013 \\
\hline Camellia & Anthracnose & Accumulated $\mathrm{H}_{2} \mathrm{O}_{2}$, defense-related enzymes, and soluble protein & Li and Zhu 2013 \\
\hline Broccoli & Native microflora & Antimicrobial coating served as carriers for bioactive compounds & Alvarez et al. 2013 \\
\hline Sycamore & - & Enhanced the production of $\mathrm{H}_{2} \mathrm{O}_{2}$ and nitric oxide & Malerba et al. 2012 \\
\hline Rice & Sheath blight & Induced activity of defense-related enzymes & Liu et al. 2012 \\
\hline Safflower; sunflower & Salt stress & Induced the activity of antioxidant enzymes & Jabeen and Ahmad 2013 \\
\hline Tomato & - & Accumulated phosphatidic acid and nitric oxide & Raho et al. 2011 \\
\hline Hypericum perforatum & - & Produced xanthone-rich extracts with antifungal activity & Tocci et al. 2011 \\
\hline Apricot & Fruit rot & Direct inhibition activity & Lou et al. 2011 \\
\hline Radish & Cadmium stress & $\begin{array}{l}\text { Promoted the uptake of nutrients, nitrogen, potassium and } \\
\text { phosphorous, decreased cadmium concentration }\end{array}$ & Farouk et al. 2011 \\
\hline Barley & Mildew & Induced stomatal closure & Koers et al. 2011 \\
\hline Pear & Fungal pathogens in storage & Significantly increased defense-related enzymes activity & Meng et al. 2010 \\
\hline Grape & Botrytis bunch rot & $\begin{array}{l}\text { Direct antifungal activity and induction of defense-related } \\
\text { enzymes activities }\end{array}$ & Reglinski et al. 2010 \\
\hline Sweet cherry & Short shelf life & $\begin{array}{l}\text { Maintained quality attributes and extended the postharvest } \\
\text { life by inducing defense-related enzymes activities }\end{array}$ & Dang et al. 2010 \\
\hline Fresh-cut mangoes & Short shelf life & $\begin{array}{l}\text { Combined effects of postharvest heat treatment and chitosan } \\
\text { coating on quality and antimicrobial proprieties of fresh- } \\
\text { cut mangoes }\end{array}$ & Djioua et al. 2010 \\
\hline Maize & Low-temperature stress & $\begin{array}{l}\text { Increased the chilling tolerance of maize seedlings and } \\
\text { induced higher activities of antioxidative enzymes }\end{array}$ & Guan et al. 2009 \\
\hline Pearl millet & Downy mildew & $\begin{array}{l}\text { Elevated nitric oxide accumulation and activated early } \\
\text { defense reactions }\end{array}$ & Manjunatha et al. 2009 \\
\hline Pearl millet & Downy mildew & Increased the level of the defense-related enzymes & Manjunatha et al. 2008 \\
\hline Tobacco & Tobacco necrosis virus & Elicited callose apposition and abscisic acid accumulation & Iriti et al. 2006 \\
\hline
\end{tabular}

in the chitin-glucan degradation of fungal cell walls. Not unexpectedly, increased resistance could be achieved in plants simultaneously expressing high levels of both enzymes (Dumas-Gaudot et al. 1996). Many reports revealed that chitosan was able to induce resistance in the host by increasing chitinase and $\beta$-1,3-glucanase activities in cucumbers, pears, and peaches (El-Ghaouth et al. 1994; Meng et al. 2010; Ma et al. 2013). More interestingly, El-Ghaouth et al. (1992) found that chitosan only induced chitinase activity in wounded strawberry fruit but not in intact fruit and suggested that the nonporous strawberry cuticle might have physically separated chitosan from the tissue and, therefore, prevented chitosan from inducing chitinase (Romanazzi et al. 2009).

Chitosan-mediated induction resulted in the rapid activation of a subset of genes called pathogenesis-related genes, generally regarded as the genes that functionally develop disease resistance. Chitosan appeared to employ multiple modes to increase pathogenesis-related gene function, including activating cell surface or membrane receptors and internal effects on the plant's DNA conformation that influenced gene transcription in turn (Hadwiger 1999). In oat leaves, chitosan strongly activated the expression of general defense response genes, such as pathogenesis-related 10 (Hoat et al. 2013). In rice seedlings, chitosan triggered a set of defense responses, including the transcriptional upregulation of defense-related genes ( $\beta$-1,3-glucanase and chitinase) and accumulation of pathogenesis-related protein 1 . Furthermore, chitosans of low molecular weight were more effective at inducing the described defense responses than those of higher molecular weight (Lin et al. 2005).

\subsection{Defense-related enzymes}

As an exogenous elicitor, chitosan can induce resistance in the host by increasing the activities of several defense-related enzymes, such as phenylalanine ammonia-lyase, peroxidase, polyphenol oxidase, catalase, and superoxide dismutase activity. 
Phenylalanine ammonia-lyase is an enzyme that catalyzes the biotransformation of L-phenylalanine to ammonia and trans-cinnamic acid (MacDonald and D'Cunha 2007). As the key enzyme of phenyl propanoid pathway, phenylalanine ammonia-lyase is induced in host tissues following pathogen infection of plant tissues and by abiotic elicitor treatments, such as chitosan (Khan et al. 2003). Phenylalanine ammonialyase activity in the skin of table grape berries sprayed with $1.0 \%$ chitosan was 2-fold higher than that in the untreated control. Both preharvest and postharvest chitosan treatments significantly reduced the incidence of gray mold and were effective to control decay of table grapes (Romanazzi et al. 2002). Similar induced activity of phenylalanine ammonialyase was also reported to increase in response to elicitation with chitosan in rice and wheat ( $\mathrm{Li}$ et al. 2013a).

Peroxidase is widely distributed in higher plants and contributes to the oxidization of phenolic and enodiolic cosubstrates to quinones and generates hydrogen peroxide (Borsani et al. 2001). While the exact mechanisms have yet to be elucidated, peroxidase is known to play a part in increasing plants' defenses against pathogens (Karthikeyan et al. 2005). Chitosan treatment significantly increased peroxidase activity in flesh around wound of pear fruit (Meng et al. 2010). Peroxidase activity in the peach treated with $5 \mathrm{~g} / \mathrm{L}$ chitosan reached the peak at $24 \mathrm{~h}$, and it was almost 3-fold as that in control fruit. Moreover, peroxidase gene expression in chitosan-treated fruit maintained relatively higher than that in control fruit (Ma et al. 2013).

Polyphenol oxidase, catalyzing the phenolic substances to synthesize lignin, is ubiquitous among angiosperms and assumed to be involved in plant defense by promoting the formation of lignin that contributes to the reinforcement of the cell wall structure preventing the penetration of pathogen (Chen et al. 2000; Li and Steffens 2002; Li and Zhu 2013). Chitosan significantly increased polyphenol oxidase activity in rice seedlings following inoculation of two rice pathogens (Xanthomonas oryzae pv. oryzae and X. oryzae pv. oryzicola) (Li et al. 2013a). When injected into date palm roots at three concentrations $(0.1,0.5$, and $1 \mathrm{mg} / \mathrm{mL})$, chitosan elicited peroxidase expression activity, particularly at the concentration of $1 \mathrm{mg} / \mathrm{mL}$, and increased the level of phenolic compounds (El-Hassni et al. 2004). Plant phenolics have been in the center of a myriad of discoveries related to plant defenses to different pathogens (Nicholson and Hammerschmidt 1992; Treutter 2006).

Catalase, which is involved in the degradation of $\mathrm{H}_{2} \mathrm{O}_{2}$ into $\mathrm{H}_{2} \mathrm{O}$ and $\mathrm{O}_{2}$, is the major $\mathrm{H}_{2} \mathrm{O}_{2}$-scavenging enzyme in all aerobic organisms. Accumulating evidence indicated that catalase played an important role in plant defense, aging, and senescence (Yang and Poovaiah 2002). The increase of catalase activity was detected both in the chilling-sensitive and chilling-tolerant maize seedlings after priming with chitosan at three concentrations $(0.25,0.50$, and $0.75 \%, w / v)$ (Guan et al. 2009). It suggested that seed priming with chitosan might accelerate their germination speed and improve their tolerance to stress conditions. Similar increase of chitosaninduced catalase activity in peach suggested that chitosan exhibited antioxidant capability (Ma et al. 2013), as enhancement of catalase is helpful to eliminate free radicals (Chen 2008). Thus, it was speculated that chitosan might delay repining and senescence of plant by regulating antioxidant enzyme.

\subsection{Defense-related secondary metabolites accumulation}

Secondary metabolites are not directly involved in growth or reproduction, but they are often involved with plant defense. Elicitation is a tool extensively used for enhancing secondary metabolite yields. Chitosan is an example of elicitors inducing defense-related secondary metabolites accumulation in plant tissue.

\subsubsection{Phytoalexins}

Phytoalexins are antifungal and antioxidative compounds synthesized by plants in response to a pathogen challenge or induced by treatment with elicitors such as chitosan. In a narrow sense, phytoalexins tend to fall into several classes including terpenoids, isoflavonoid, and alkaloids; however, researchers often find it convenient to extend the definition to include all phytochemicals that are part of the plant's defensive arsenal.

Hadwiger and Beckman (1980) demonstrated that chitosan at concentration as low as $0.9 \mu \mathrm{g} / \mathrm{mL}$ elicited phytoalexin induction and inhibited germination of macroconidia. When chitosan was applied to pea pod tissue with or prior to Fusarium solani, the tissue was protected from infection. Similar to the inhibitory effect, phytoalexin production was affected by molecular weight and degree of acetylation of chitosan. The highest phytoalexin production was achieved in grapevine leaves within $48 \mathrm{~h}$ of incubation with chitosan at $200 \mu \mathrm{g} / \mathrm{mL}$ with a molecular weight of 1,500 and a degree of acetylation of $20 \%$ (Aziz et al. 2006). It was observed that pretreating cottonseeds with chitosan markedly increased cotton resistance to vascular wilt caused by $F$. oxysporum f. sp. vasinfectum. All chitosan derivates tested significantly stimulated phytoalexin (gossypol) production in roots more than stems, which greatly increased with a maximum of $1.16 \mathrm{mg} /$ $5 \mathrm{~g}$ in chitosan-treated fresh root tissue (Awadalla and Mahmoud 2005).

Therefore, chitosan can be extensively used for inducing phytoalexin accumulation in plant tissue and enhancing secondary metabolite yields (Komaraiah et al. 2003; Eilenberg et al. 2010). Ruta graveolens L. accumulated 
various types of secondary metabolites, such as coumarins and alkaloids; both of them could be regarded as phytoalexin and defense tools for plants against pathogenic fungi. Chitosan induced a severalfold increase in the concentrations of coumarins and fluoroquinolone alkaloids. Such a dramatic increase suggested that chitosan might be participating in the natural resistance mechanisms of Ruta graveolens. The application of chitosan as elicitors may be considered a promising prospect in the biotechnological production of biologically active phytoalexins and other secondary metabolites (Orlita et al. 2008).

\subsubsection{Lignin}

Lignin is closely associated with cellulose and hemicellulose in hardening and strengthening of plant cell wall (Rajan et al. 2005). Lignification renders the cell wall more resistant to mechanical pressure during penetration by fungal appressoria as well as more water resistant and thus less accessible to cell wall degrading enzymes. Thus, it forms a barrier offering protection against microbial and chemical degradation. In the plant-pathogen interaction, the lignification of infected plant cell walls is a mechanism for disease resistance and provides plants with effective protection against pathogens. The synthesis of precursors of lignin and phenolic acids having antimicrobial activity in wheat seeds was stimulated by chitosan treatment. Chitosan also inhibited fungal transmission to the primary roots of germinating seedlings. Results suggested that chitosan controlled seed-borne Fusarium graminearum infection and increased the resistance in seedlings by stimulating the accumulation of phenolics and lignin (Bhaskara Reddy et al. 1999). Treatment of wounded wheat leaves with a partially acetylated chitosan hydrolysate elicited lignification at wound margins and invoked significant increases in phenylalanine ammonia-lyase, peroxidase expression, and catalase activities (Mitchell et al. 1994).

\subsubsection{Suberization}

Suberization is another common mechanism of cell wall for disease resistance in plants. Suberization is a tissue-specific process, whereby cell walls become impregnated with a poly(phenolic) matrix coincident with the deposition of a poly(aliphatic) matrix between the plasmalemma and carbohydrate cell wall (Bernards et al. 1999). As a biogenic elicitor, chitosan locally and systemically stimulated wound healing in potato tuber tissues by increasing the number of wound periderm layers, accelerating the development of cork cambium (phellogen), and inducing proteinase inhibitors (Ozeretskovskaia et al. 2009).

\subsubsection{Phenolic compounds}

Phenylalanine ammonia-lyase is the key enzyme in the phenylpropanoid pathway and is involved in the synthesis of phenolic compounds, which are associated with the expression of disease resistance (Treutter 2006). Since chitosan produced elevated phenylalanine ammonia-lyase activity in plant, the levels of total phenolic content may also increase following chitosan treatments.

Increase in phenylalanine ammonia-lyase activity on chitosan treatment and subsequent augmentation of total phenolic contents has been previously reported in soybean leaves. Application of chitosan led to elevated activity of phenylalanine ammonia-lyase in soybean leaf tissues but markedly declined at $48 \mathrm{~h}$. It was observed the total phenolic content was elevated at $60 \mathrm{~h}$ in chitosan-treated plants, showing a positive correlation between enzyme activity and total phenolic content (Romanazzi et al. 2002). In Eurasian traditional medicine Greek oregano, 200 and 500 ppm chitosan oligosaccharide treatments promoted plant height growth, whereas 50 and $200 \mathrm{ppm}$ chitosan oligosaccharide upregulated the content of polyphenols significantly (38 and $29 \%$, respective1y) (Yin et al. 2012). Chitosan also increased total phenolics in date palm seedlings of two cultivars, Jihel (JHL, susceptible) and Bousthami noire (BSTN, resistant). The highest phenolic levels were recorded at a chitosan concentration of $1 \mathrm{mg} / \mathrm{mL}$ 30 days after incubation, when they were about three times higher than in the control roots (Nicholson and Hammerschmidt 1992). As the major phenolic compound in sweet basil, rosmarinic acid has been reported to have various bioactive properties such as antioxidant, antimicrobial, and anti-inflammatory activities. The total amount of phenolic compounds significantly increased after chitosan treatments, especially rosmarinic acid that increased 2.5 times by $0.1 \%$ chitosan treatment. Therefore, due to the significant induction of phenolic compounds, the corresponding antioxidant activity increased at least 3.5-fold (Kim et al. 2005).

Chlorogenic acid, another phenolic compound, is an important biosynthetic intermediate, for example in lignin biosynthesis. Studies showed that chlorogenic acid displayed antibacterial and antifungal activity against certain microorganisms (Sung and Lee 2010; Hemaiswarya et al. 2011; Atanasova-Penichon et al. 2012). In ginseng callus cultures, accumulation of phenolic compounds was increased 3-fold within $12 \mathrm{~h}$ after $1 \%$ chitosan treatment. HPLC analysis revealed significantly higher levels of chlorogenic acid. Enhanced activity of phenylalanine ammonia-lyase and peroxidase and enhanced levels of phenolic compounds, for example, chlorogenic acid, all point to an enhanced defense response in ginseng rusty roots (Rahman and Punja 2005). 


\subsubsection{Callose}

Callose exists in the cell walls of a wide variety of higher plants. It plays important roles during many processes in plant development and in response to numerous biotic and abiotic stresses, such as wounding and pathogens infection. Callosecontaining cell-wall appositions, called papillae, are effective barriers that are induced at the sites of attack during the relatively early stages of pathogen invasion (Luna et al. 2011). Chitosan was known to have eliciting activities leading to callose formation in host plants in response to microbial infections (Iriti and Faoro 2008; El-Hadrami et al. 2010; Jabeen and Ahmad 2013). After treatments with $0.1 \%$ chitosan, tobacco plants significantly reduced tobacco necrosis virus-induced necrotic lesions and enhanced inducible defenses, which was associated with a network of callose deposits, micro-oxidative bursts, and micro-hypersensitive responses (Bol et al. 1990). In fact, chitosan induced callose deposition at pathogen entry points during the initial hours of pathogen inoculation (Iriti et al. 2006). The elicited callose apposition in plant tissues exerted a determinant role in limiting microbial spread in the early phase of pathogen infection (Iriti and Faoro 2008).

\subsection{Signal transduction}

During the long-term coevolution, plants and pathogens have evolved an intricate relationship. Pathogens have developed an array of offensive strategies to parasitize plants, and in turn, plants have evolved a complex multilayered defense system to prevent infection (Nurnberger et al. 2004; Chisholm et al. 2006). Based on the mechanisms mentioned above and other literatures, chitosan can behave like a general elicitor, exhibiting a wide variety of defense responses to pathogens infestation, including increases in chitinase and $\beta-1,3-$ glucanase, defense-related enzymes, phytoalexins, and secondary metabolites by expressing related responsive genes and defense genes. There appears to be multiple modes by which chitosan can increase these gene expressions and functions, including activating cell surface or membrane receptors and internal effects on the plant's DNA conformation that influence gene transcription in turn (Hoat et al. 2013). It is attractive to elucidate the role of chitosan in plant immunity regulation.

\subsubsection{Extracellular signal perception of chitosan}

The first step in the elicitor-induced transduction pathway is the recognition of the signaling molecule by a specific receptor (Benhamou 1996). In the dicotyledonous model plant Arabidopsis, chitin elicitor receptor kinase 1 (CERK1), a LysM receptor kinase, has been shown to play a critical role in fungal microbe-associated molecular pattern perception
(Miya et al. 2007). Petutschnig et al. (2010) suggested that CERK1 was not only required for chitin but also for chitosan perception. However, a recent work showed that defense response genes were upregulated by chitosan, both in wildtype and in the chitin-insensitive cerkl mutant, indicating that chitosan is perceived through a CERK1-independent pathway (Povero et al. 2011).

A lectin specific for glucosamine oligomers has been purified by chitosan affinity chromatography from cultured cells of Rubus. Sodium dodecyl sulfate-polyacrylamide gel electroploresis (SDS-PAGE) showed that the lectin appeared as a membrane-bound protein of molecular weight $67 \mathrm{kDa}$ with two apparent binding sites, i.e., the tetrasaccharide and the hexasaccharide, but did not exhibit any affinity for the cellotetraose, $\mathrm{N}$-acetylchitotetraose, and maltotetraose. Considering its affinity for chitosan, the lectin may be a receptor for chitosan-derived oligomers with elicitor activity, which ultimately trigger plant defense reactions (Liénart et al. 1991).

Unfortunately, research papers about the binding protein or receptor of chitosan are few. To our knowledge, the lectin is the only receptor discovered that is likely to bind to chitosan. However, whether there are binding proteins for chitosan on other plants remains to be further studied.

\subsubsection{Intracellular signal perception of chitosan}

Besides the signal perception via cell surface or membrane receptors, many researchers (Hadwiger et al. 1989; Hadwiger 1999; Dumas-Gaudot et al. 1996) demonstrated that chitosan exhibited internal effects on the plant's DNA conformation and regulated at the chromatin level directly since chitosan entered most regions of the cell. The highly positively charged chitosan possessing a strong affinity for the negative charged phosphates of the DNA backbone, especially the minor groove of DNA (Liu et al. 2005), may compete with histone proteins containing lower densities of positive charges (Isaac et al. 2009). Chitosan treatments to the pea endocarp tissue resulted in subtle DNA fragmentation of the pea DNA within $2.5 \mathrm{~h}$, indicating that it can affect DNA in vivo (Hadwiger et al. 1997). As a pathogenesis-related gene elicitor, chitosan may alter chromatin via competition with basic nuclear proteins for DNA attachment sites, potentially displacing H2A/ H2B histones (Hadwiger 2008).

\subsubsection{Signal transduction of chitosan with other signal molecules}

When the extracellular signaling molecule chitosan activates the specific receptor on the cell membrane or located intracellular, one or more second messengers transmit the signal into the cell and create a series of physiological responses. In the 
above process termed as signal transduction, a single signal can be amplified and develop a complex signaling networks. According to published literatures, reactive oxygen species (ROS), $\mathrm{Ca}^{2+}$, nitric oxide (NO), ethylene (ET), jasmonic acid (JA), salicylic acid (SA), and abscisic acid (ABA) all involved in chitosan-mediated signal pathway.

The oxidative burst, a rapid and transient production of huge amounts of ROS, is one of the earliest responses to microbial pathogen attack (Wojtaszek 1997) and has been shown to occur upon chitosan elicitation (Luna et al. 2011). The production of ROS included hydrogen peroxide $\left(\mathrm{H}_{2} \mathrm{O}_{2}\right)$, superoxide $\left(\mathrm{O}_{2}{ }^{-}\right)$, hydroxyl radicals $\left(\mathrm{OH}^{\circ}\right)$, and so on. As the important signals mediating defense gene activation, ROS are centrally involved in the induction of plant disease resistance responses. $\mathrm{H}_{2} \mathrm{O}_{2}$ served as a signal of oxidative stress and activation of signaling cascades as a result of the early response of the plant to biotic stress (Mejía-Teniente et al. 2013). In sycamore cultured cells, $0.01 \%$ chitosan induced an accumulation of $\mathrm{H}_{2} \mathrm{O}_{2}$ reaching about $50 \mathrm{nmol} / \mathrm{g}$ fresh weight after $24 \mathrm{~h}$ (Jabeen and Ahmad 2013). In Arabidopsis cell suspension cultures, chitosan induced the accumulation of $\mathrm{H}_{2} \mathrm{O}_{2}$ within $1 \mathrm{~h}$. The addition of ascorbic acid $\left(\mathrm{a}_{2} \mathrm{O}_{2}\right.$ scavenger) blocked the formation of the brown coloration (chemical interactions took place in the presence of $\mathrm{H}_{2} \mathrm{O}_{2}$ ) confirming that chitosan induced $\mathrm{H}_{2} \mathrm{O}_{2}$ accumulation in the Arabidopsis cell cultures (Ndimba et al. 2003). Similar results were obtained in chitosan-treated sweet peppers and tomatoes (Orozco-Cardenas and Ryan 1999; MejíaTeniente et al. 2013).

Calcium metabolism is intimately related to ROS signaling. Increase in cytosolic $\mathrm{Ca}^{2+}$ is also one of the fastest responses upon pathogen infection, and the use of specific inhibitors showed that $\mathrm{Ca}^{2+}$ influx was required for ROS production after elicitation (Blume et al. 2000; Grant et al. 2000). It was demonstrated that the polycationic nature of chitosan might lead to membrane disturbance through its interaction with negatively charged membrane phospholipids (Shibuya and Minami 2001). According to published reports, treatments that disrupt plasma membrane integrity are often accompanied by alterations of cell $\mathrm{Ca}^{2+}$ signaling (Pizzo et al. 2002). In suspension-cultured cells of Glycine max, synthesis of callose started within 20 min of treatment with chitosan and parallels over hours of the accumulation of 1,3-linked glucose in the wall. However, chitosan-induced callose formation was not possible without the presence of external $\mathrm{Ca}^{2+}$ and partly recovered upon restoration of $15 \mu \mathrm{M} \mathrm{Ca}^{2+}$ (Köhle et al. 1985). In Arabidopsis, chitosan induced transient elevations in the concentration of free cytosolic $\mathrm{Ca}^{2+}$ and stomatal closure in guard cells (Klüsener et al. 2002).

NO, another second messenger recently established in plants, is involved in the plant defense response of a growing list of plant-pathogen interactions (Klüsener et al. 2002; Lamattina et al. 2003; Neill et al. 2003). Chitosan treatment showed downy mildew disease protection of $79.8 \%$ over the untreated control and elevated $\mathrm{NO}$ accumulation in pearl millet seedlings beginning from $2 \mathrm{~h}$ postinoculation. Howev$\mathrm{er}$, the degree of protection was reduced after $\mathrm{NO}$ scavenger cPTIO [2-(4-carboxyphenyl)-4,4,5,5-tetramethylimidazoline1-oxyl-3-oxide potassium salt] or NO synthase inhibitor LNAME ( $N$-nitro-L-arginine methyl ester hydrochloride) treatment; this indicated the possible involvement of $\mathrm{NO}$ in chitosan-induced resistance (Hadwiger 2013). In tomato cells, chitosan induced a rapid NO production, as well as the formation of phosphatidic acid by activating both phospholipase $\mathrm{D}$ and phospholipase C/diacylglycerol kinase. Pretreatment with NO scavenger c-PTIO inhibited the activation of either phospholipase-mediated signaling pathway. This indicated that NO was required for phosphatidic acid generation via both the phospholipase $\mathrm{D}$ and phospholipase $\mathrm{C} /$ diacylglycerol kinase pathway during plant defense response in chitosanelicited cells (Tocci et al. 2011).

Phytohormones are not only instrumental in regulating developmental processes in plants but also play important roles for the plant's responses to biotic and abiotic stresses (Halim et al. 2006). For example, disease resistance in Arabidopsis is regulated by multiple signal transduction pathways in which SA, JA, and ET function as key signaling molecules in mediating or orchestrating biotic/abiotic stress responses. SA is involved in the systemic acquired resistance in which a pathogenic attack on one part of the plant induces resistance in other parts, whereas JA and ET are central signaling molecules in the induced systemic resistance. JA, the terminal product of the octadecanoid pathway, has been proposed to be part of a signal transduction pathway that regulates the induction of defenseresponse genes in plants against pathogen invasion. In rice, chitosan caused a rapid increase in the endogenous JA level within $3 \mathrm{~min}$. Furthermore, the rise in JA level by chitosan was again significantly higher upon wounding, and reached a peak at $60 \mathrm{~min}$ versus $30 \mathrm{~min}$ in wounded leaves, suggesting that this observed increase is a specific response to applied chitosan (Rakwal et al. 2002). An oilseed rape cDNA microarray containing 8,095 expressed sequence tags was used to analyze the Brassica napus gene expression changes elicited by oligochitosan. Transcript levels for 136 genes were induced 2-fold or more in oligochitosantreated seedlings compared with control seedlings. Results of semiquantification RT-PCR showed that an important JA synthase gene, a JA-mediated defense required for kinase gene, an ET receptor gene, and two ET responsive element binding protein genes were induced by oligochitosan, suggesting that oligochitosan activated the plant self-defense through JA/ET signaling pathway (Yin et al. 2006). 
Recently, in a series of plant pathosystems, it has been shown that the intensity and speed of callose deposition are regulated by ABA. ABA, also called abscisin II and dormin, is now known to be the case only in a small number of plants. ABA-mediated signaling transduction also plays an important role in plant responses to environmental stress and plant pathogens (Seo and Koshiba 2002). Chitosan treatment reduced tobacco necrosis virus lesion area per leaf by $95.2 \%$ in respect to untreated controls. Furthermore, chitosan application elicited both callose apposition and ABA accumulation in leaf tissues, at 12 and $24 \mathrm{~h}$ after treatment, respectively. Besides, treatment with the ABA inhibitor nordihydroguaiaretic acid, before chitosan application, reduced both callose deposition and plant resistance to the virus, thus indicating the involvement of ABA in chitosan-mediated processes. It was indicated that the increase of ABA synthesis induced by chitosan played an important role in enhancing callose deposition (Iriti and Faoro 2009).

Based on the above analysis, chitosan activated the plant self-defense through different signaling pathways or involved in signal transduction as a regulatory molecules. Despite extensive research, the mechanisms of how chitosan acted upon plant immunity regulation have not been elucidated clearly. It is believed that the mode of action of chitosan is probably more complex than assumed above, involving a series of events, which need to study further in the future.

\section{Conclusion and future perspectives}

During the last 150 years, ever since the discovery of chitosan, considerable progresses have been made in understanding and exploiting its new properties as well as new applications. As reviewed in this article, the versatile chitosan, naturally occurring compound, possessing broad-spectrum antimicrobial effects and plant innate immunity elicited activities, has potential in agriculture with regard to controlling plant diseases. Its application may counteract the wide use of chemical pesticides, in part at least. The polysaccharide chitosans represent a renewable source of natural biodegradable polymers and meet with the emergence of more and more food safe problems.

Though much work has been done, there are still many unclear points in the mechanisms of chitosan that inhibited the growth of pathogens and induced the plant immunity. Appropriate chemical modification could significantly enhance its antimicrobial activities, improve the physical and chemical properties, and make it more suitable for field applications. In the case of antimicrobial mode of action, future work should aim at clarifying the actual target molecule on the cell surface or other intracellular targets. It would have potential values to construct gene mutant strains for further study on the antimicrobial mechanisms. Combined transcriptome and proteome analysis of key defense genes and proteins will enhance our understanding of the complicated chitosan-mediated signal pathway and enable better biotechnological applications in plant disease control. A wider comprehensive knowledge of the mechanism of action of chitosan in pathogens and plants will increase the chance of its successful application to control disease spread in plants. We also suggest comprehensive cooperation among global chemists, microbiologists, phytophysiologists, and agronomists to better exploit chitosan's antimicrobial properties, plant innate immunity elicited activity, and biotechnological potential for agricultural sustainable development.

Acknowledgments This work was supported by grants from the National Natural Science Foundation of China (31101502, 31370062), the Program of Natural Science Foundation of the Jiangsu Higher Education Institutions of China (11KJD210002), Qing Lan Project of Jiangsu Province (2014), and the Project Funded by the Priority Academic Program Development of Jiangsu Higher Education Institutions (PAPD).

\section{References}

Abbasi NA, Iqbal Z, Maqbool M, Hafiz IA (2009) Postharvest quality of mango (Mangifera indica L.) fruit as affected by chitosan coating. Pak J Bot 41:343-357

Abro MA, Lecompte F, Bardin M, Nicot PC (2013) Nitrogen fertilization impacts biocontrol of tomato gray mold. Agron Sustain Dev. doi:10. 1007/s13593-013-0168-3

Allan CR, Hadwiger LA (1979) The fungicidal effect of chitosan on fungi of varying cell composition. Exp Mycol 3:285-287. doi:10.1016/ S0147-5975(79)80054-7

Alvarez MV, Ponce AG, Moreira MR (2013) Antimicrobial efficiency of chitosan coating enriched with bioactive compounds to improve the safety of fresh cut broccoli. LWT - Food Sci Technol 50:78-87. doi: 10.1016/j.lwt.2012.06.021

Amborabé B-E, Bonmort J, Fleurat-Lessard P, Roblin G (2008) Early events induced by chitosan on plant cells. J Exp Bot 59:2317-2324. doi:10.1093/jxb/ern096

Atanasova-Penichon V, Pons S, Pinson-Gadais L, Picot A, Marchegay G, Bonnin-Verdal MN, Ducos C, Barreau C, Roucolle J, Sehabiague P, Carolo P, Richard-Forget F (2012) Chlorogenic acid and maize ear rot resistance: a dynamic study investigating Fusarium graminearum development, deoxynivalenol production, and phenolic acid accumulation. Mol Plant Microbe Interact 25:1605-1616. doi:10.1094/MPMI-06-12-0153-R

Atkinson HA, Daniels A, Read ND (2002) Live-cell imaging of endocytosis during conidial germination in the rice blast fungus, Magnaporthe grisea. Fungal Genet Biol 37:233-244. doi:10.1016/ S1087-1845(02)00535-2

Awadalla OA, Mahmoud YA-G (2005) New chitosan derivatives induced resistance to Fusarium wilt disease through phytoalexin (Gossypol) production. Sains Malays 34:141-146

Aziz A, Trotel-Aziz P, Dhuicq L, Jeandet P, Couderchet M, Vernet G (2006) Chitosan oligomers and copper sulfate induce grapevine defense reactions and resistance to gray mold and downy mildew. Phytopathology 96:1188-1194. doi:10.1094/PHYTO-96-1188

Badawy ME, Rabea EI, Taktak NE (2014) Antimicrobial and inhibitory enzyme activity of N-(benzyl) and quaternary N-(benzyl) chitosan 
derivatives on plant pathogens. Carbohydr Polym 111:670-682. doi: 10.1016/j.carbpol.2014.04.098

Benhamou N (1992) Ultrastructural and cytochemical aspects of chitosan on Fusarium oxysporum f. sp. radices-lycopersici, agent of tomato crown and root rot. Phytopathology 82:1185-1193

Benhamou N (1996) Elicitor-induced plant defence pathways. Trends Plant Sci 1:233-240. doi:10.1016/1360-1385(96)86901-9

Bernards MA, Fleming WD, Llewellyn DB, Priefer R, Yang XL, Sabatino A, Plourde GL (1999) Biochemical characterization of the suberization-associated anionic peroxidase of potato. Plant Physiol 121:135-146. doi:10.1104/pp. 121.1.135

Bhaskara Reddy MV, Arul J, Angers P, Couture L (1999) Chitosan treatment of wheat seeds induces resistance to Fusarium graminearum and improves seed quality. J Agric Food Chem 47:1208-1216

Bhatnagar A, Sillanpää M (2009) Applications of chitin- and chitosanderivatives for the detoxification of water and wastewater - a short review. Adv Colloid Interfac 152:26-38. doi:10.1016/j.cis.2009.09. 003

Blume B, Nürnberger T, Nass N, Scheel D (2000) Receptor-mediated increase in cytoplasmic free calcium required for activation of pathogen defense in parsley. Plant Cell 12:1425-1440. doi:10. $2307 / 3871140$

Bol JF, Linthorst HJM, Cornelissen BJC (1990) Plant pathogenesisrelated proteins induced by virus infection. Annu Rev Phytopathol 28:113-138. doi:10.1146/annurev.py.28.090190.000553

Borsani O, Valpuesta V, Botella MA (2001) Evidence for a role of salicylic acid in the oxidative damage generated by $\mathrm{NaCl}$ and osmotic stress in Arabidopsis seedlings. Plant Physiol 126:1024 1030. doi:10.1104/pp. 126.3.1024

Chatterjee S, Chatterjee BP, Guha AK (2014) A study an antifungal activity of water-soluble chitosan against Macrophomina phaseolina. Int J Biol Macromol 67:452-457. doi:10.1016/j. ijbiomac.2014.04.008

Chen YP (2008) Isatis indigotica seedlings derived from laser stimulated seeds showed improved resistance to elevated UV-B. Plant Growth Regul 55:73-79. doi:10.1007/s10725-008-9258-7

Chen C, Belanger RR, Benhamou N, Paulitz TC (2000) Defense enzymes induced in cucumber roots by treatment with plant growthpromoting rhizobacteria (PGPR) and Pythium aphanidermatum. Physiol Mol Plant P 56:13-23. doi:10.1006/pmpp.1999.0243

Chirkov SN (2002) The antiviral activity of chitosan. Appl Biochem Micro 38:1-8

Chirkov SN, Il'ina AV, Surgucheva NA, Letunova EV, Varitsev YA, Tatarinova NY, Varlamov VP (2001) Effect of chitosan on systemic viral infection and some defense responses in potato plants. Russ $\mathrm{J}$ Plant Physl 48:774-779. doi:10.1023/A:1012508625017

Chisholm ST, Coaker G, Day B, Staskawicz BJ (2006) Host-microbe interactions: shaping the evolution of the plant immune response. Cell 124:803-814. doi:10.1016/j.cell.2006.02.008

Chung YC, Chen CY (2008) Antibacterial characteristics and activity of acid-soluble chitosan. Bioresource Technol 99:2806-2814. doi:10. 1016/j.biortech.2007.06.044

Chung YC, Su YP, Chen CC, Jia G, Wang HL, Wu JC, Lin JG (2004) Relationship between antibacterial activity of chitosan and surface characteristics of cell wall. Acta Pharmacol Sin 25:932-936

Come V, Deschamps A, Mertial A (2003) Bioactive packaging materials from edible chitosan polymer-antimicrobial activity assessment on dairy-related contaminants. J Food Sci 68:2788-2792. doi:10.1111/ j.1365-2621.2003.tb05806.x

Cota-Arriola O, Cortez-Rocha MO, Burgos-Hernández A, EzquerraBrauer JM, Plascencia-Jatomea M (2013) Controlled release matrices and micro/nanoparticles of chitosan with antimicrobial potential: development of new strategies for microbial control in agriculture. $\mathrm{J}$ Sci Food Agric 93:1525-1536. doi:10.1002/jsfa.6060

Dang QF, Yan JQ, Li Y, Cheng XJ, Liu CS, Chen XG (2010) Chitosan acetate as an active coating material and its effects on the storing of
Prunus avium L. J Food Sci 75:S125-S131. doi:10.1111/j.17503841.2009.01483.x

Davydova VN, Naqorskaia VP, Gorbach VI, Kalitnik AA, Reunov AV, Solov'eva TF, Ermak IM (2011) Chitosan antiviral activity: dependence on structure and depolymerization method. Prikl Biokhim Mikrobiol 47:113-118. doi:10.1134/S0003683811010042

Djioua T, Charles F, Freire M, Filgueiras H, Ducamp-Collin MN, Sallanon H (2010) Combined effects of postharvest heat treatment and chitosan coating on quality of fresh-cut mangoes (Mangifera indica L.). Int J Food Sci Tech 45:849-855. doi:10.1111/j.13652621.2010.02209.x

Dodane V, Vilivalam VD (1998) Pharmaceutical applications of chitosan. Pharm Sci Technol To 1:246-253. doi:10.1016/S1461-5347(98) 00059-5

Du WL, Niu SS, Xu YL, Xu ZR, Fan CL (2009) Antibacterial activity of chitosan tripolyphosphate nanoparticles loaded with various metal ions. Carbohydr Polym 75:385-389. doi:10.1016/j.carbpol.2008.07.039

Dumas-Gaudot E, Slezak S, Dassi B, Pozo MJ, Gianinazzi-Pearson V, Gianinazzi S (1996) Plant hydrolytic enzymes (chitinases and $\beta-1,3$ glucanases) in root reactions to pathogenic and symbiotic microorganisms. Plant Soil 185:211-221. doi:10.1007/BF02257526

Dutta PK, Tripathi S, Mehrotra GK, Dutta J (2009) Perspectives for chitosan based antimicrobial films in food applications. Food Chem 114:1173-1182. doi:10.1016/j.foodchem.2008.11.047

Eilenberg H, Pnini-Cohen S, Rahamim Y, Sionov E, Segal E, Carmeli S, Zilberstein A (2010) Induced production of antifungal naphthoquinones in the pitchers of the carnivorous plant Nepenthes khasiana. J Exp Bot 61:911-922. doi:10.1093/jxb/erp359

El-Ghaouth A, Arul J, Grenier J, Asselin A (1992) Antifungal activity of chitosan on two post-harvest pathogens of strawberry fruits. Phytopathology 82:398-402

El-Ghaouth A, Arul J, Grenier J, Benhamou N, Asselin A, Belanger R (1994) Effect of chitosan on cucumber plants: suppression of Pythium aphinodermatum and induction of defense reactions. Phytopathology 84:313-320

El-Hadrami A, Adam LR, El-Hadrami I, Daayf F (2010) Chitosan in plant protection. Mar Drugs 8:968-987. doi:10.3390/md8040968

El-Hassni M, El-Hadrami A, Daayf F, Barka EA, El-Hadrami I (2004) Chitosan, antifungal product against Fusarium oxysporum f. sp. albedinis and elicitor of defence reactions in date palm roots. Phytopathol Mediterr 43:195-204

Elsenhans B, Blume R, Lembcke B, Caspary WF (1983) A new class of inhibitors for in vitro small intestinal transport of sugars and amino acids in the rat. Biochim Biophys Acta 727:135-143. doi:10.1016/ 0005-2736(83)90377-2

Farouk S, Mosa AA, Taha AA, Ibrahim HM, EL-Gahmery AM (2011) Protective effect of humic acid and chitosan on radish (Raphanus sativus, L. var. sativus) plants subjected to cadmium stress. J Stress Physiol Bioch 7:99-116

Fitza KNE, Payn KG, Steenkamp ET, Myburg AA, Naidoo S (2013) Chitosan application improves resistance to Fusarium circinatum in Pinus patula. S Afr J Bot 85:70-78. doi:10.1016/j.sajb.2012.12.006

Fondevilla S, Rubiales D (2012) Powdery mildew control in pea. A review. Agron Sustain Dev 32:401-409

Galván MI, Akuaku J, Cruz I, Cheetham J, Golshani A, Smith ML (2013) Disruption of protein synthesis as antifungal mode of action by chitosan. Int J Food Microbiol 164:108-112. doi:10.1016/j. ijfoodmicro.2013.03.025

García-Rincóna J, Vega-Pérezb J, Guerra-Sánchezb MG, HernándezLauzardoa AN, Peña-Díazc A, Velázquez-Del Vallea MG (2010) Effect of chitosan on growth and plasma membrane properties of Rhizopus stolonifer (Ehrenb.:Fr.) Vuill. Pestic Biochem Phys 97: 275-278. doi:10.1016/j.pestbp.2010.03.008

Geisberger G, Gyenge EB, Hinger D, Käch A, Maake C, Patzke GR (2013) Chitosan-thioglycolic acid as a versatile antimicrobial agent. Biomacromolecules 14:1010-1017. doi:10.1021/bm3018593 
Goy RC, Britto D, Assis OBG (2009) A review of the antimicrobial activity of chitosan. Polímeros 19:241-247. doi:10.1590/S010414282009000300013

Grant M, Brown I, Adams S, Knight M, Ainslie A, Mansfield J (2000) The RPM1 plant disease resistance gene facilitates a rapid and sustained increase in cytosolic calcium that is necessary for the oxidative burst and hypersensitive cell death. Plant J 23:441-450. doi:10.1046/j.1365-313x.2000.00804.x

Guan YJ, Hu J, Wang XJ, Shao CX (2009) Seed priming with chitosan improves maize germination and seedling growth in relation to physiological changes under low temperature stress. J Zhejiang Univ Sci B 10:427-433. doi:10.1631/jzus.B0820373

Guo ZY, Chen R, Xing RE, Liu S, Yu HH, Wang PB, Li CP, Li PC (2006) Novel derivatives of chitosan and their antifungal activities in vitro. Carbohyd Res 341:351-354. doi:10.1016/j.carres.2005.11.002

Hadwiger LA (1999) Host-parasite interactions: elicitation of defense responses in plants with chitosan. EXS 87:185-200. doi:10.1007/ 978-3-0348-8757-1 13

Hadwiger LA (2008) Pea-Fusarium solani interactions contributions of a system toward understanding disease resistance. Phytopathology 98:372-379. doi:10.1094/PHYTO-98-4-0372

Hadwiger LA (2013) Multiple effects of chitosan on plant systems: solid science or hype. Plant Sci 208:42-49. doi:10.1016/j.plantsci.2013. 03.007

Hadwiger LA. Klosterman SK. Chang MM. Friel P. Hosick HL (1997) Chitosan heptamer alters DNA, induces defense genes in plants and induces the accumulation of gene p53 product in animal cells. In: Domard A, Roberts GAF, Varum KM (eds.) In Advances in Chitin Science. Jacques Andre Publisher, Lyon, vol. II, pp102-109

Hadwiger LA, Beckman JM (1980) Chtosan as a component of PeaFusarium solani interactions. Plant Physiol 66:205-211. doi:10. 1104/pp. 66.2.205

Hadwiger LA, Chiang C, Victory S, Horovitz D (1989) Chitin and chitosan: sources, chemistry, biochemistry, physical properties and applications. Elsevier Applied Science, London

Halim VA, Vess A, Scheel D, Rosahl S (2006) The role of salicylic acid and jasmonic acid in pathogen defence. Plant Biol 8:307-313. doi: 10.1055/s-2006-924025

Helander IM, Nurmiaho-Lassila EL, Ahvenainen R, Rhoades J, Roller S (2001) Chitosan disrupts the barrier properties of the outer membrane of Gram-negative bacteria. Int J Food Microbiol 71:235-244. doi:10.1016/S0168-1605(01)00609-2

Hemaiswarya S, Soudaminikkutty R, Narasumani ML, Doble M (2011) Phenylpropanoids inhibit protofilament formation of Escherichia coli cell division protein FtsZ. J Med Microbiol 60:1317-1325. doi:10.1099/jmm.0.030536-0

Hoat TX, Nakayashiki H, Yang Q, Tosa Y, Mayama S (2013) Molecular cloning of the apoptosis-related calcium-binding protein AsALG-2 in Avena sativa. Mol Plant Pathol 14:222-229. doi:10.1111/j.13643703.2012.00844.x

Hsu SH, Chang YB, Tsai CL, Fu KY, Wang SH, Tseng HJ (2011) Characterization and biocompatibility of chitosan nanocomposites. Colloid Surface B 85:198-206. doi:10.1016/j.colsurfb.2011.02.029

Hu Y, Cai J, Du YM, Lin JG, Wang CG, Xiong KJ (2009) Preparation and anti-TMV activity of guanidinylated chitosan hydrochloride. J Appl Polym Sci 112:3522-3528. doi:10.1002/app.29959

Iriti M, Faoro F (2008) Abscisic acid is involved in chitosan-induced resistance to tobacco necrosis virus (TNV). Plant Physiol Biochem 46:1106-1111. doi:10.1016/j.plaphy.2008.08.002

Iriti M, Faoro F (2009) Chitosan as a MAMP, searching for a PRR. Plant Signal Behav 4:66-68. doi:10.4161/psb.4.1.7408

Iriti M, Sironi M, Gomarasca S, Casazza AP, Soave C, Faoro F (2006) Cell death-mediated antiviral effect of chitosan in tobacco. Plant Physiol Biochem 44:893-900. doi:10.1016/j.plaphy.2006.10.009

Isaac J, Hartney SL, Druffel K, Hadwiger LA (2009) The non-host disease resistance response in peas; alterations in phosphorylation and ubiquitination of HMG A and histones H2A/H2B. Plant Sci 177:439-449. doi:10.1016/j.plantsci.2009.07.007

Issam ST, Adele MG, Adele CP, Stephane G, Veronique C (2005) Chitosan polymer as bioactive coating and film against Aspergillus niger contamination. J Food Sci 70:100-104

Jabeen N, Ahmad R (2013) The activity of antioxidant enzymes in response to salt stress in safflower (Carthamus tinctorius L.) and sunflower (Helianthus annuus L.) seedlings raised from seed treated with chitosan. J Sci Food Agric 93:1699-1705. doi:10.1002/jsfa. 5953

Je JY, Kim SK (2006) Chitosan derivatives killed bacteria by disrupting the outer and inner membrane. J Agric Food Chem 54:6629-6633. doi:10.1021/jf061310p

Karthikeyan M, Jayakumar V, Radhika K, Bhaskaran R, Velazhahan R, Alice D (2005) Induction of resistance in host against the infection of leaf blight pathogen (Alternaria palandui) in onion (Allium cepa var aggregatum). Indian J Biochem Biophys 42:371-377

Khan W, Prithiviraj B, Smith DL (2003) Chitosan and chitin oligomers increase phenylalanine ammonia-lyase and tyrosine ammonia-lyase activities in soybean leaves. J Plant Physiol 160:859-863. doi:10. 1078/0176-1617-00905

Kim HJ, Chen F, Wang X, Rajapakse NC (2005) Effect of chitosan on the biological properties of sweet basil (Ocimum basilicum L.). J Agric Food Chem 53:3696-3701. doi:10.1021/jf0480804

Kim H, Tator CH, Shoichet MS (2011) Chitosan implants in the rat spinal cord: biocompatibility and biodegradation. J Biomed Mater Res A 97:395-404. doi:10.1002/jbm.a.33070

Klüsener B, Young JJ, Murata Y, Allen GJ, Mori IC, Hugouvieux V, Schroeder JI (2002) Convergence of calcium signaling pathways of pathogenic elicitors and abscisic acid in Arabidopsis guard cells. Plant Physiol 130:2152-2163

Koers S, Guzel-Deger A, Marten I, Roelfsema MR (2011) Barley mildew and its elicitor chitosan promote closed stomata by stimulating guard-cell S-type anion channels. Plant J 68:670-680. doi:10. 1111/j.1365-313X.2011.04719.x

Köhle H, Jeblick W, Poten F, Blaschek W, Kauss H (1985) Chitosanelicited callose synthesis in soybean cells as a $\mathrm{Ca}^{2+}$-dependent process. Plant Physiol 77:544-551

Komaraiah P, Ramakrishna SV, Reddanna P, Kavi Kishor PB (2003) Enhanced production of plumbagin in immobilized cells of Plumbago rosea by elicitation and in situ adsorption. J Biotechnol 101:181-187. doi:10.1016/S0168-1656(02)00338-3

Kong M, Chen XG, Liu CS, Liu CG, Meng XH, Yu LJ (2008) Antibacterial mechanism of chitosan microspheres in a solid dispersing system against $E$. coli. Colloid Surface B 65:197-202. doi: 10.1016/j.colsurfb.2008.04.003

Kong M, Chen XG, Xing K, Park HJ (2010) Antimicrobial properties of chitosan and mode of action: a state of the art review. Int $\mathrm{J}$ Food Microbiol 144:51-63. doi:10.1016/j.ijfoodmicro.2010.09.012

Lamattina L, Garcia-Mata C, Graziano M, Pagnussat G (2003) Nitric oxide: the versatility of an extensive signal molecule. Annu Rev Plant Biol 54:109-136. doi:10.1146/annurev.arplant.54.031902. 134752

Lambert PA (2002) Cellular impermeability and uptake of biocides and antibiotics in gram-positive bacteria and mycobacteria. J Appl Microbiol 31:46S-54S. doi:10.1046/j.1365-2672.92.5s1.7.x

Lee DS, Je JY (2013) Gallic acid-grafted-chitosan inhibits foodborne pathogens by a membrane damage mechanism. J Agric Food Chem 61:6574-6579. doi:10.1021/jf401254g

Li L, Steffens JC (2002) Overexpression of polyphenol oxidase in transgenic tomato plants results in enhanced bacterial disease resistance. Planta 215:239-247. doi:10.1007/s00425-002-0750-4

Li SJ, Zhu TH (2013) Biochemical response and induced resistance against anthracnose (Colletotrichum camelliae) of camellia (Camellia pitardii) by chitosan oligosaccharide application. For Path 43:67-76. doi:10.1111/j.1439-0329.2012.00797.x 
Li B, Wang X, Chen RX, Huangfu WG, Xie GL (2008) Antibacterial activity of chitosan solution against Xanthomonas pathogenic bacteria isolated from Euphorbia pulcherrima. Carbohyd Polym 72: 287-292. doi:10.1016/j.carbpol.2007.08.012

Li B, Liu BP, Shan CL, Ibrahim M, Lou YH, Wang YL, Xie GL, Li HY, Sun GC (2013a) Antibacterial activity of two chitosan solutions and their effect on rice bacterial leaf blight and leaf streak. Pest Manag Sci 69:312-320. doi:10.1002/ps.3399

Li B, Shi Y, Shan CL, Zhou Q, Ibrahim M, Wang YL, Wu GX, Li HY, Xie GL, Sun GC (2013b) Effect of chitosan solution on the inhibition of Acidovorax citrulli causing bacterial fruit blotch of watermelon. $\mathrm{J}$ Sci Food Agric 93:1010-1015. doi:10.1002/jsfa.5812

Li XS, Min M, Du N, Gu Y, Hode T, Naylor M, Chen D, Nordquist RE, Chen WR (2013c) Chitin, chitosan, and glycated chitosan regulate immune responses: the novel adjuvants for cancer vaccine. Clin Dev Immunol 2013:1-8. doi:10.1155/2013/387023

Liang C, Yuan F, Liu F, Wang Y, Gao Y (2014) Structure and antimicrobial mechanism of $\varepsilon$-polylysine-chitosan conjugates through Maillard reaction. Int J Biol Macromol. doi:10.1016/j.ijbiomac. 2014.07.012

Liénart Y, Gautier C, Domard A (1991) Isolation from Rubus cellsuspension cultures of a lectin specific for glucosamine oligomers. Planta 184:8-13. doi:10.1007/BF00208229

Lin W, Hu X, Zhang W, Rogers WJ, Cai W (2005) Hydrogen peroxide mediates defence responses induced by chitosans of different molecular weights in rice. J Plant Physiol 162:937-944. doi:10.1016/j. jplph.2004.10.003

Liu XF, Guan YL, Yang DZ, Li Z, Yao KD (2001) Antibacterial action of chitosan and carboxymethylated chitosan. J Appl Polym Sci 79: 1324-1335. doi:10.1002/1097-4628(20010214)79:7<1324::AIDAPP210>3.0.CO;2-L

Liu H, Du YM, Wang XH, Sun LP (2004) Chitosan kills bacteria through cell membrane damage. Int J Food Microbiol 95:147-155. doi:10. 1016/j.ijfoodmicro.2004.01.022

Liu W, Sun S, Cao Z, Zhang X, Yao K, Lu WW, Luk KD (2005) An investigation on the physicochemical properties of chitosan/DNA polyelectrolyte complexes. Biomaterials 26:2705-2711. doi:10. 1016/j.biomaterials.2004.07.038

Liu H, Tian WX, Li B, Wu GX, Ibrahim M, Tao ZY, Wang YL, Xie GL, Li HY, Sun GC (2012) Antifungal effect and mechanism of chitosan against the rice sheath blight pathogen, Rhizoctonia solani. Biotechnol Lett 34:2291-2298. doi:10.1007/s10529-012-1035-Z

Lou MM, Zhu B, Muhammad I, Li B, Xie GL, Wang YL, Li HY, Sun GC (2011) Antibacterial activity and mechanism of action of chitosan solutions against apricot fruit rot pathogen Burkholderia seminalis. Carbohyd Res 346:1294-1301. doi:10.1016/j.carres.2011.04.042

Luna E, Pastor V, Robert J, Flors V, Mauch-Mani B, Ton J (2011) Callose deposition: a multifaceted plant defense response. Mol Plant Microbe Interact 24:183-193. doi:10.1094/MPMI-07-10-0149

Ma ZX, Yang LY, Yan HX, Kennedy JF, Meng XH (2013) Chitosan and oligochitosan enhance the resistance of peach fruit to brown rot. Carbohydr Polym 94:272-277. doi:10.1016/j.carbpol.2013.01.012

MacDonald MJ, D'Cunha GB (2007) A modern view of phenylalanine ammonia lyase. Biochem Cell Biol 85:273-282. doi:10.1139/O07-018

Madihally SV, Matthew HW (1999) Porous chitosan scaffolds for tissue engineering. Biomaterials 20:1133-1142. doi:10.1016/S01429612(99)00011-3

Malerba M, Crosti P, Cerana R (2012) Defense/stress responses activated by chitosan in sycamore cultured cells. Protoplasma 249:89-98. doi: 10.1007/s00709-011-0264-7

Manjunatha G, Roopa KS, Prashanth GN, Shetty HS (2008) Chitosan enhances disease resistance in pearl millet against downy mildew caused by Sclerospora graminicola and defence-related enzyme activation. Pest Manag Sci 64:1250-1257. doi:10.1002/ps.1626

Manjunatha G, Niranjan-Raj S, Prashanth GN, Deepak S, Amruthesh $\mathrm{KN}$, Shetty HS (2009) Nitric oxide is involved in chitosan-induced systemic resistance in pearl millet against downy mildew disease. Pest Manag Sci 65:737-743. doi:10.1002/ps.1710

Mansilla AY, Albertengo L, Rodríguez MS, Debbaudt A, Zúñiga A, Casalongué CA (2013) Evidence on antimicrobial properties and mode of action of a chitosan obtained from crustacean exoskeletons on Pseudomonas syringae pv. tomato DC3000. Appl Microbiol Biotechnol 97:6957-6966. doi:10.1007/s00253-013-4993-8

Mejía-Teniente L, Duran-Flores FD, Chapa-Oliver AM, Torres-Pacheco I, Cruz-Hernández A, González-Chavira MM, Ocampo-Velázquez RV, Guevara-González RG (2013) Oxidative and molecular responses in Capsicum annuum L. after hydrogen peroxide, salicylic acid and chitosan foliar applications. Int J Mol Sci 14:10178-10196. doi:10.3390/ijms140510178

Meng XH, Yang LY, Kennedy JF, Tian SP (2010) Effects of chitosan and oligochitosan on growth of two fungal pathogens and physiological properties in pear fruit. Carbohydr Polym 81:70-75. doi:10.1016/j. carbpol.2010.01.057

Mi FL, Tan YC, Liang HF, Sung HW (2002) In vivo biocompatibility and degradability of a novel injectable-chitosan-based implant. Biomaterials 23:181-191. doi:10.1016/S0142-9612(01)00094-1

Mitchell HJ, Hall JL, Barber MS (1994) Elicitor-induced cinnamyl alcohol dehydrogenase activity in lignifying wheat (Triticum aestivum L.) leaves. Plant Physiol 104:551-556

Miya A, Albert P, Shinya T, Desaki Y, Ichimura K, Shirasu K, Narusaka Y, Kawakami N, Kaku H, Shibuya N (2007) CERK1, a LysM receptor kinase, is essential for chitin elicitor signaling in Arabidopsis. Proc Natl Acad Sci U S A 104:19613-19618. doi:10. 1073/pans.0705147104

Ndimba BK, Chivasa S, Hamilton JM, Simon WJ, Slabas AR (2003) Proteomic analysis of changes in the extracellular matrix of Arabidopsis cell suspension cultures induced by fungal elicitors. Proteomics 3:1047-1059. doi:10.1002/pmic.200300413

Neill SJ, Desikan R, Hancock JT (2003) Nitric oxide signalling in plants. New Phytol 159:11-35. doi:10.1046/j.1469-8137.2003.00804.x

Nicholson RL, Hammerschmidt R (1992) Phenolic compounds and their role in disease resistance. Annu Rev Phytopathol 30:369-389. doi: 10.1146/annurev.py.30.090192.002101

No HK, Park NY, Lee SH, Meyers SP (2002) Antibacterial activity of chitosans and chitosan oligomers with different molecular weights. Int J Food Microbiol 74:65-72. doi:10.1016/S0168-1605(01) 00717-6

Nurnberger T, Brunner F, Kemmerking B, Piater L (2004) Innate immunity in plants and animals: striking similarities and obvious differences. Immunol Rev 198:249-266. doi:10.1111/j.0105-2896.2004.0119.x

Orgaz B, Lobete MM, Puga CH, Jose CS (2011) Effectiveness of chitosan against mature biofilms formed by food related bacteria. Int J Mol Sci 12:817-828. doi:10.3390/ijms12010817

Orlita A, Sidwa-Gorycka M, Paszkiewicz M, Malinski E, Kumirska J, Siedlecka EM, Łojkowska E, Stepnowski P (2008) Application of chitin and chitosan as elicitors of coumarins and fluoroquinolone alkaloids in Ruta graveolens L. (common rue). Biotechnol Appl Biochem 51:91-96. doi:10.1042/BA20070200

Orozco-Cardenas M, Ryan CA (1999) Hydrogen peroxide is generated systemically in plant leaves by wounding and systemin via the octadecanoid pathway. Proc Natl Acad Sci U S A 96:6553-6557. doi:10.1073/pnas.96.11.6553

Ozeretskovskaia OL, Vasiukova NI, Chalenko GI, Gerasimova NG, Revina TA, Valueva TA (2009) Wound healing and induced resistance in potato tubers. Prikl Biokhim Mikrobiol 45:220-224. doi:10. 1134/S0003683809020148

Palma-Guerrero J, Huang IC, Jansson HB, Salinas J, Lopez-Llorca LV, Read ND (2009) Chitosan permeabilizes the plasma membrane and kills cells of Neurospora crassa in an energy dependent manner. Fungal Genet Biol 46:585-594. doi:10.1016/j.fgb.2009.02.010

Palma-Guerrero J, Lopez-Jimenez JA, Pérez-Berná AJ, Huang IC, Jansson HB, Salinas J, Villalaín J, Read ND, Lopez-Llorca LV 
(2010) Membrane fluidity determines sensitivity of filamentous fungi to chitosan. Mol Microbiol 75:1021-1032. doi:10.1111/j. 1365-2958.2009.07039.x

Park S-I, Daeschel MA, Zhao Y (2004) Functional properties of antimicrobial lysozyme-chitosan composite films. J Food Sci 69:215-221. doi:10.1111/j.1365-2621.2004.tb09890.x

Park Y, Kim MH, Park SC, Cheong H, Jang MK, Nah JW, Hahm KS (2008) Investigation of the antifungal activity and mechanism of action of LMWS-chitosan. J Microbiol Biotechn 18:1729-1734

Petutschnig EK, Jones AM, Serazetdinova L, Lipka U, Lipka V (2010) The lysin motif receptor-like kinase (Lysm-RLK) CERK1 is a major chitin-binding protein in Arabidopsis thaliana and subject to chitininduced phosphorylation. J Bio Chem 285:28902-28911. doi:10. 1074/jbc.M110.116657

Pillai CKS, Paul W, Sharma CP (2009) Chitin and chitosan polymers: chemistry, solubility and fiber formation. Prog Polym Sci 34:641678. doi:10.1016/j.progpolymsci.2009.04.001

Pizzo P, Giurisato E, Tassi M, Benedetti A, Pozzan T, Viola A (2002) Lipid rafts and $\mathrm{T}$ cell receptor signaling: a critical re-evaluation. Eur J Immunol 32:3082-3091. doi:10.1002/1521-4141(200211) 32:11<3082::AID-IMMU3082>3.0.CO;2-2

Povero G, Loreti E, Pucciariello C, Santaniello A, Di Tommaso D, Di Tommaso G, Kapetis D, Zolezzi F, Piaggesi A, Perata P (2011) Transcript profiling of chitosan-treated Arabidopsis seedlings. J Plant Res 124:619-629. doi:10.1007/s10265-010-0399-1

Qiu M, Wu C, Ren G, Liang X, Wang X, Huang J (2014) Effect of chitosan and its derivatives as antifungal and preservative agents on postharvest green asparagus. Food Chem 155:105-111. doi:10. 1016/j.foodchem.2014.01.026

Raafat D, Bargen KV, Haas A, Sahl H-G (2008) Insights into the mode of action of chitosan as an antibacterial compound. Appl Environ Microb 74:3764-3773. doi:10.1128/AEM.00453-08

Rabea EI, Steurbaut W (2010) Chemically modified chitosans as antimicrobial agents against some plant pathogenic bacteria and fungi. Plant Protect Sci 4:149-158

Rabea EI, Badawy ME-T, Stevens CV, Smagghe G, Steurbaut W (2003) Chitosan as antimicrobial agent: applications and mode of action. Biomacromolecules 4:1457-1465. doi:10.1021/bm034130m

Rabea EI, Badawy MEI, Steurbaut W, Stevens CV (2009) In vitro assessment of $N$-(benzyl)chitosan derivatives against some plant pathogenic bacteria and fungi. Eur Polym J 45:237-245. doi:10. 1016/j.eurpolymj.2008.10.021

Rahman M, Punja ZK (2005) Biochemistry of ginseng root tissues affected by rusty root symptoms. Plant Physiol Biochem 43:11031114. doi:10.1016/j.plaphy.2005.09.004

Raho N, Ramirez L, Lanteri ML, Gonorazky G, Lamattina L, ten Have A, Laxalt AM (2011) Phosphatidic acid production in chitosan-elicited tomato cells, via both phospholipase D and phospholipase C/diacylglycerol kinase, requires nitric oxide. J Plant Physiol 168: 534-539. doi:10.1016/j.jplph.2010.09.004

Rajan A, Kurup JG, Abraham TE (2005) Biosoftening of arecanut fiber for value added products. Biochem Eng J 25:237-242. doi:10.1016/ j.bej.2005.05.011

Rakwal R, Tamogami S, Agrawal GK, Iwahashi H (2002) Octadecanoid signaling component "burst" in rice (Oryza sativa L.) seedling leaves upon wounding by cut and treatment with fungal elicitor chitosan. Biochem Biophys Res Commun 295:1041-1045. doi:10. 1016/S0006-291X(02)00779-9

Ray SD (2011) Potential aspects of chitosan as pharmaceutical excipient. Acta Pol Pharm 68:619-622

Reglinski T, Elmer PAG, Taylor JT, Wood PN, Hoyte SM (2010) Inhibition of Botrytis cinerea growth and suppression of botrytis bunch rot in grapes using chitosan. Plant Pathol 59:882-890. doi:10. 1111/j.1365-3059.2010.02312.x

Romanazzi G, Nigro F, Ippolito A, Di Venere D, Salerno M (2002) Effects of pre- and postharvest chitosan treatments to control storage grey mold of table grapes. J Food Sci 67:1862-1867. doi:10.1111/j. 1365-2621.2002.tb08737.x

Romanazzi G, Mlikota Gabler F, Margosan D, Mackey BE, Smilanick JL (2009) Effect of chitosan dissolved in different acids on its ability to control postharvest gray mold of table grape. Phytopathology 99: 1028-1036. doi:10.1094/PHYTO-99-9-1028

Sanford PA (2003) Commercial sources of chitin and chitosan and their utilization. In: Varum KM, Domard A, SmidsrØd O (eds) Advances in Chitin Science, vol 6. NTNU, Trondheim, pp 35-42

Selitrennikoff CL (2001) Antifungal proteins. Appl Environ Microbiol 67:2883-2894. doi:10.1128/AEM.67.7.2883-2894.2001

Seo M, Koshiba T (2002) Complex regulation of ABA biosynthesis in plants. Trends Plant Sci 7:41-48. doi:10.1016/S1360-1385(01) 02187-2

Seyfarth F, Schliemann S, Elsner P, Hipler U-C (2008) Antifungal effect of high- and low-molecular-weight chitosan hydrochloride, carboxymethyl chitosan, chitosan oligosaccharide and $N$-acetyl-dglucosamine against Candida albicans, Candida krusei and Candida glabrata. Int J Pharm 353:139-148. doi:10.1016/j. ijpharm.2007.11.029

Shi ZL, Neoh KG, Kang ET, Wang W (2006) Antibacterial and mechanical properties of bone cement impregnated with chitosan nanoparticles. Biomaterials 27:2440-2449. doi:10.1016/j.biomaterials. 2005.11.036

Shibuya N, Minami E (2001) Oligosaccharide signalling for defence responses in plant. Physiol Mol Plant P 59:223-233. doi:10.1006/ pmpp. 2001.0364

Silva TH, Alves A, Ferreira BM, Oliveira JM, Reys LL, Ferreira RJF, Sousa RA, Silva SS, Mano JF, Reis RL (2012) Materials of marine origin: a review on polymers and ceramics of biomedical interest. Int Mater Rev 57:276-306(31). doi:10.1179/1743280412Y. 000000002

Singla AK, Chawla M (2001) Chitosan: some pharmaceutical and biological aspects-an update. J Pharm Pharmacol 53:1047-1067. doi: 10.1211/0022357011776441

Su XW, Zivanovic S, D'Souza DH (2009) Effect of chitosan on the infectivity of murine norovirus, feline calicivirus, and bacteriophage MS2. J Food Protect 72:2623-2628

Sudarshan NR, Hoover DG, Knorr D (1992) Antibacterial action of chitosan. Food Biotechnol 6:257-272. doi:10.1080/ 08905439209549838

Sun B, Zhang L, Yang L, Zhang F, Norse D, Zhu Z (2012) Agricultural non-point source pollution in China: causes and mitigation measures. Ambio 41(4):370-379. doi:10.1007/s13280-012-0249-6

Sung WS, Lee DG (2010) Antifungal action of chlorogenic acid against pathogenic fungi, mediated by membrane disruption. Pure Appl Chem 82:219-226. doi:10.1351/PAC-CON-09-01-08

Tan HL, Ma R, Lin CC, Liu ZW, Tang TT (2013) Quaternized chitosan as an antimicrobial agent: antimicrobial activity, mechanism of action and biomedical applications in orthopedics. Int J Mol Sci 14:1854 1869. doi:10.3390/ijms14011854

Tang H, Zhang P, Kieft TL, Ryan SJ, Baker SM, Wiesmann WP, Rogelj S (2010) Antibacterial action of a novel functionalized chitosanarginine against gram-negative bacteria. Acta Biomater 6:25622571. doi:10.1016/j.actbio.2010.01.002

Tayel AA, Moussa S, Opwis K, Knittel D, Schollmeyer E, NickischHartfiel A (2010) Inhibition of microbial pathogens by fungal chitosan. Int J Biol Macromol 47:10-14. doi:10.1016/j.ijbiomac.2010. 04.005

Tocci N, Simonetti G, D'Auria FD, Panella S, Palamara AT, Valletta A, Pasqua G (2011) Root cultures of Hypericum perforatum subsp. angustifolium elicited with chitosan and production of xanthone-rich extracts with antifungal activity. Appl Microbiol Biotechnol 91: 977-987. doi:10.1007/s00253-011-3303-6

Toshkova R, Manolova N, Gardeva E, Ignatova M, Yossifova L, Rashkov I, Alexandrov M (2010) Antitumor activity of quaternized chitosan- 
based electrospun implants against Graffi myeloid tumor. Int J Pharm 400:221-233. doi:10.1016/j.ijpharm.2010.08.039

Treutter D (2006) Significance of flavonoids in plant resistance: a review. Environ Chem Lett 4:147-157. doi:10.1007/s10311-006-0068-8

Upadhyaya L, Singh J, Agarwal V, Tewari RP (2013) Biomedical applications of carboxymethyl chitosans. Carbohydr Polym 91:452-466. doi:10.1016/j.carbpol.2012.07.076

Vaara M (1992) Agents that increase the permeability of the outer membrane. Microbiol Rev 56:395-411

Vallance J, Déniel F, Floch GL, Guérin-Dubrana L, Blancard D, Rey P (2011) Pathogenic and beneficial microorganisms in soilless cultures. Agron Sustain Dev 31:191-203. doi:10.1051/agro/2010018

Van Loon LC, Van Kammen A (1970) Polyacrylamide disc electrophoresis of the soluble leaf proteins from Nicotiunu tubucum var. 'Samsun' and 'Samsun NN': II. Changes in protein constitution after infection with tobacco mosaic virus. Virology 40:199-201

Vishu KAB, Varadaraj MC, Gowda LR, Tharanathan RN (2005) Characterization of chito-oligosaccharides prepared by chitosanolysis with the aid of papain and Pronase, and their bactericidal action against Bacillus cereus and Escherichia coli. Biochem J 391:167-175. doi:10.1042/BJ20050093

Wang W, Wang SX, Guan HS (2012) The antiviral activities and mechanisms of marine polysaccharides: an overview. Mar Drugs 10: 2795-2816. doi:10.3390/md10122795

Wiśniewska-Wrona M, Niekraszewicz A, Ciechańska D, Pospieszny H, Orlikowski LB (2007) Biological properties of chitosan degradation products. Polish Chitin Society, Monograph XII, pp 149-156

Wojtaszek P (1997) Oxidative burst: an early plant response to pathogen infection. Biochem J 322:681-692

Xing K, Chen XG, Li YY, Liu CS, Liu CG, Cha DS, Park HJ (2008) Antibacterial activity of oleoyl-chitosan nanoparticles: a novel antibacterial dispersion system. Carbohydr Polym 74:114-120. doi:10. 1016/j.carbpol.2008.01.024

Xing K, Chen XG, Kong M, Liu CS, Cha DS, Park HJ (2009a) Effect of oleoyl-chitosan nanoparticles as a novel antibacterial dispersion system on viability, membrane permeability and cell morphology of Escherichia coli and Staphylococcus aureus. Carbohydr Polym 76:17-22. doi:10.1016/j.carbpol.2008.09.016

Xing K, Chen XG, Liu CS, Cha DS, Park HJ (2009b) Oleoyl-chitosan nanoparticles inhibits Escherichia coli and Staphylococcus aureus by damaging the cell membrane and putative binding to extracellular or intracellular targets. Int J Food Microbiol 132:127-133. doi:10. 1016/j.ijfoodmicro.2009.04.013

Yang T, Poovaiah BW (2002) Hydrogen peroxide homeostasis: activation of plant catalase by calcium/calmodulin. Proc Natl Acad Sci U S A 99:4097-4102. doi:10.1073/pnas.052564899

Ye XL, Li XG, Yuan LJ, Ge LH, Zhang BS, Zhou SB (2007) Interaction of houttuyfonate homologues with the cell membrane of grampositive and gram-negative bacteria. Colloid Surface A 301:412418. doi:10.1016/j.colsurfa.2007.01.012

Yin H, Li S, Zhao X, Du Y, Ma X (2006) cDNA microarray analysis of gene expression in Brassica napus treated with oligochitosan elicitor. Plant Physiol Biochem 44:910-916. doi:10.1016/j. plaphy.2006. 10.002

Yin H, Fretté XC, Christensen LP, Grevsen K (2012) Chitosan oligosaccharides promote the content of polyphenols in Greek oregano (Origanum vulgare ssp. hirtum). J Agric Food Chem 60:136-143. doi:10.1021/jf204376j

Younes I, Hajji S, Frachet V, Rinaudo M, Jellouli K, Nasri M (2014) Chitin extraction from shrimp shell using enzymatic treatment. antitumor, antioxidant and antimicrobial activities of chitosan. Int J Biol Macromol 69:489-498. doi:10.1016/j.ijbiomac.2014.06.013

Zaharoff DA, Rogers CJ, Hance KW, Schlom J, Greiner JW (2007) Chitosan solution enhances both humoral and cell-mediated immune responses to subcutaneous vaccination. Vaccine 25:20852094. doi:10.1016/j.vaccine.2006.11.034

Zakrzewska A, Boorsma A, Brul S, Hellingwerf KJ, Klis FM (2005) Transcriptional response of Saccharomyces cerevisiae to the plasma membrane-perturbing compound chitosan. Eukaryot Cell 4:703715. doi:10.1128/EC.4.4.703-715.2005 